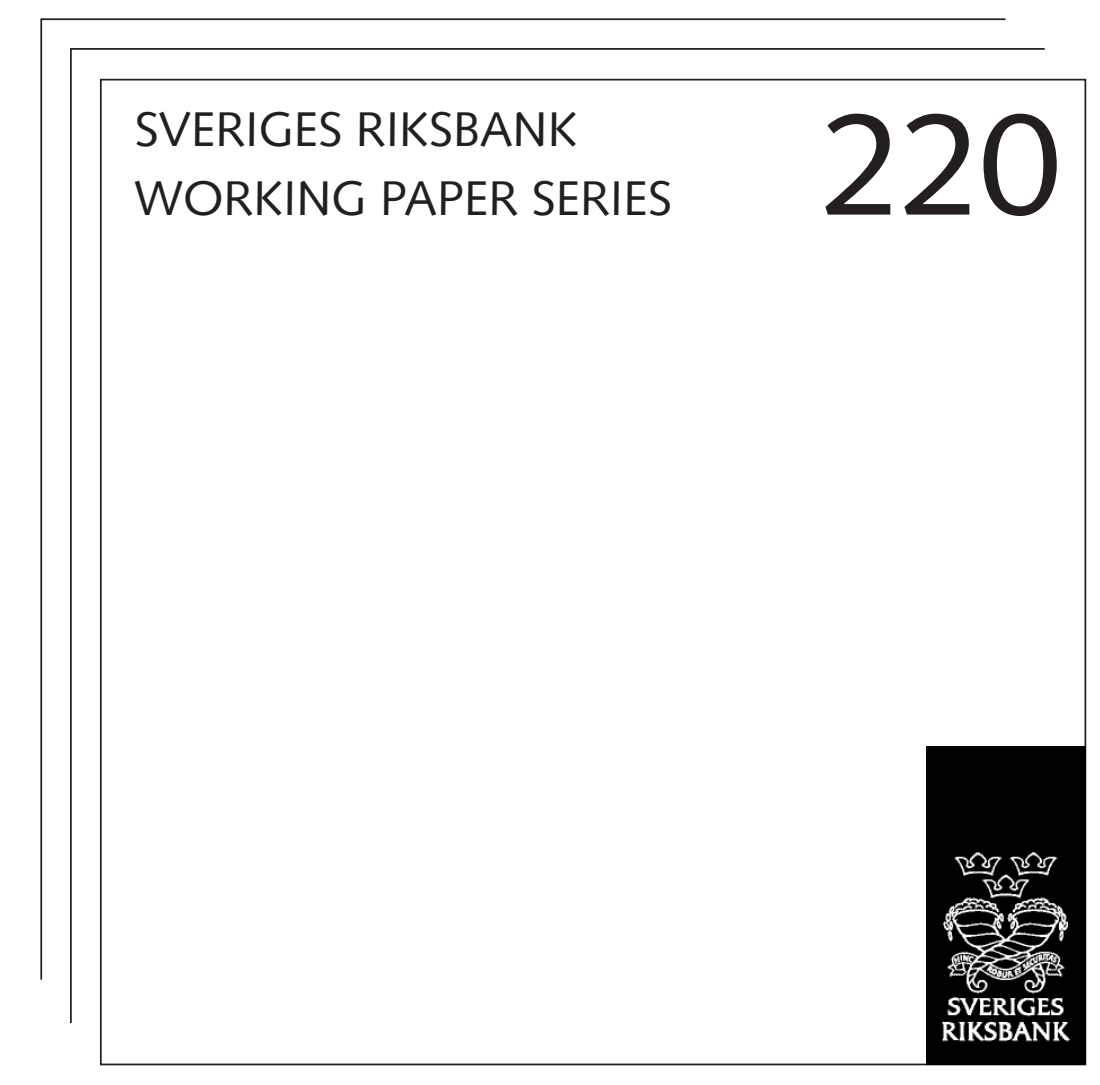

\title{
Monetary Policy Regimes and the Volatility of Long-Term Interest Rates
}

Virginia Queijo von Heideken

FEBRUARY 2008 
WORKING PAPERS ARE OBTAINABLE FROM

Sveriges Riksbank • Information Riksbank • SE-103 37 Stockholm Fax international: +4687870526

Telephone international: +4687870100

E-mail: info@riksbank.se

The Working Paper series presents reports on matters in the sphere of activities of the Riksbank that are considered to be of interest to a wider public.

The papers are to be regarded as reports on ongoing studies and the authors will be pleased to receive comments.

The views expressed in Working Papers are solely the responsibility of the authors and should not to be interpreted as reflecting the views of the Executive Board of Sveriges Riksbank. 


\title{
Monetary Policy Regimes and the Volatility of Long-Term Interest Rates*
}

\author{
Virginia Queijo von Heideken ${ }^{\dagger}$ \\ Sveriges Riksbank Working Paper Series \\ No. 220
}

February, 2008

\begin{abstract}
This paper addresses two important questions that have, so far, been studied separately in the literature. First, the paper aims at explaining the high volatility of long-term interest rates observed in the data, which is hard to replicate using standard macro models. Building a small-scale macroeconomic model and estimating it on U.S. and U.K. data, I show that the policy responses of a central bank that is uncertain about the natural rate of unemployment can explain this volatility puzzle. Second, the paper aims at shedding new light on the distinction between rules and discretion in monetary policy. My empirical results show that using yield curve data may facilitate the empirical discrimination between different monetary policy regimes and that U.S. monetary policy is best understood as originating from a discretionary regime since 1960.
\end{abstract}

Keywords: long-term interest rates, optimal monetary policy, discretion, commitment, Bayesian estimation

JEL-classification: C11, C13, C15, E32, E42, E43, E47, E50

*I am indebted to Torsten Persson for invaluable advice. I would also like to thank Jon Faust, Daria Finocchiaro, Martin Flodén, Paolo Giordani, Nils Gottfries, John Hassler, Paul Klein, Sharon Kozicki, Jesper Lindé, Lars E. O. Svensson, Paul Söderlind, Ulf Söderström, Mattias Villani, Karl Walentin, an anonymous referee and seminar participants at the IIES, Bank of Canada, Bank of Norway, Sveriges Riksbank and Uppsala University for constructive discussions and comments. I am grateful to Christina Lönnblad for editorial assistance. All remaining errors are mine. Financial support from Handelsbanken's Research Foundations is gratefully acknowledged. The views expressed in this paper are solely the responsibility of the author and should not be interpreted as reflecting the views of the Executive Board of Sveriges Riksbank.

${ }^{\dagger}$ Research Division, Sveriges Riksbank, SE-103 37 Stockholm, Sweden. Email: virginia.queijo.von.heideken@riksbank.se. 


\section{Introduction}

This paper addresses two important questions that have, so far, been studied separately in the literature. First, the paper aims at explaining the high volatility of long-term interest rates observed in the data, which is hard to replicate using standard macro models with a deterministic steady state. I show that the policy responses of a central bank that is uncertain about the natural rate of unemployment can help explain this volatility puzzle. Second, the paper aims at shedding some new light on the distinction between discretion and rules in monetary policy. Despite a great deal of theoretical work, there are few clear-cut empirical results regarding the real-word prevalence of alternative policy regimes. I show that including yield curve data may make it possible to empirically distinguish between different monetary policy regimes.

Three facts in the data on interest rates are hard to replicate in standard macro models. First, short- and long-term interest rates are strongly positively correlated (e.g., Cook and Hahn (1989)). As shown in Table 1, the correlations are positive and above 0.75 for all subperiods and all maturities. Second, as stressed in Shiller (1979), long-term rates present excess volatility: the volatility of long-term rates is higher than predicted by expectation models of the term structure. Long-term interest rates should be expected to be much smoother than short-term rates, given that we can consider long rates as an average of expected short-term interest rates, plus a premium term. However, the data in Table 1 shows that long-term interest rates are about as volatile as short rates. Third, as shown by Gürkaynak et al. (2005), long-term forward rates exhibit excess sensitivity to monetary policy announcements and macroeconomic news. These three facts cannot easily be explained by standard macro models where the long-term properties of the model are given by a deterministic steady state.

A number of papers have tried to model the behavior of long-term interest rates. Ellingsen and Söderström (2001) and Ellingsen and Söderström (2005) argue that a rise in the short-term interest rate perceived as a response to shocks to inflation or output 
will lead to higher inflation expectations and increases in long-term interest rates. On the other hand, a rise in the interest rate perceived to be triggered by a change in the preferences of the monetary policymaker towards lower inflation, will reduce inflation expectations and long-term interest rates. Ellingsen and Söderström obtain these results in models with high output and inflation inertia or a very persistent inflation target.

Using the same idea, other authors have explained the response of long-term interest rates to the central bank policy instrument using time-varying inflation targets. Shocks to the central bank inflation target change future expected inflation and thereby nominal long-term rates. Gürkaynak et al. (2005) and Beechey (2006) develop calibrated models with a variable inflation target and imperfect information which generate long-term rate volatility since expected inflation is not stationary in their models. Using a macro-finance model, Rudebusch and $\mathrm{Wu}(2008)$ also introduce time variation in the inflation target to generate responses of long rates to macro shocks. Hördahl et al. (2008) explain the volatility of long-term interest rates using a second-order approximation of a standard DSGE model with a variable inflation target, where they calibrate the autocorrelation coefficient of the inflation target to be 0.99 .

In all these papers, the high persistence of inflation and thus, the volatility of longterm rates, arises either from an accelerationist Phillips curve (where inflation is highly persistent by definition) or from very persistent inflation target shocks. In my model, on the other hand, inflation persistence is estimated rather than imposed and intrinsic to the model. Inflation persistence arises because the central bank has very persistent estimation errors about the natural rate of unemployment. The underlying idea is that when the monetary authority underestimates (overestimates) the natural rate of unemployment, it introduces a sort of inflation bias to reduce the perceived unemployment gap. Since misperceptions about the natural rate of unemployment are empirically very persistent, this rises expectations of future inflation and future short-term interest rates. Once we augment the model with the expectation hypothesis of interest rates, which es- 
tablishes a relationship between long-term and short-term interest rates, a discretionary regime can also explain the volatility puzzle.

Furthermore, in all the above mentioned papers, except Ellingsen and Söderström (2001), the volatility of long-term rates is explained by a shock to a policy objective, namely the inflation target. In other words, long-term rates move because the monetary authority changes its preferences. In my model, the policymaker's objectives are stable and long-term rates mainly move due to the incapability of the central bank to observe the natural rate. As opposed to policy preferences, my explanation is based on the undeniable fact that the central bank has to estimate the natural rate using historical data.

Alexius and Welz (2005) resort to a time-varying natural real interest rate to explain the behavior of long-term yields. However, empirical evidence shows changes in longterm yields on U.S. Treasury bonds to mainly be due to changes in long-term inflationary expectations, implying that real forward interest rates are quite stable and the term premium is small. Therefore, I abstract from variations in the real interest rate and explain long-term rate volatility through inflation expectations.

Concerning the second question of the paper, namely the empirical distinction between monetary policy regimes, a large theoretical literature analyzes the properties of monetary policy under discretion and commitment. In general, this literature considers the qualitative and not the quantitative implications of both regimes and, to my knowledge, no paper has explicitly analyzed the implication of these regimes for long-term interest rates. As pointed out by Baxter (1988) 20 years ago, it is important to use established statistical procedures for selecting among alternative models for policymaking. However, very little has been achieved on this empirical agenda and most current papers model monetary policy as a Taylor-type interest rate rule.

Empirical papers addressing the inflation bias problem in Kydland and Prescott (1977) and Barro and Gordon (1983) include Christiano and Fitzgerald (2003), Ireland 
(1999) and Ruge-Murcia (2003). The first two papers argue that their results support the Barro-Gordon model as an explanation for U.S. inflation since 1960. On the other hand, Ruge-Murcia (2003) finds that the Fed targeted the natural rate of unemployment, but gave more weight to positive than to negative unemployment deviations between 1960 and 1999.

Unlike these previous papers, I look at the problem from a different perspective and use data on long-term interest rates to distinguish between monetary policy regimes. Moreover, I assume that the monetary authority targets the natural rate of unemployment, which eliminates the Barro-Gordon type of inflation bias. In this sense, my model is closer to Clarida et al. (1999), Svensson (1997), and Woodford (1999), who stress the fact that in forward-looking models, a discretionary regime generates a dynamic loss, even if the central bank targets the natural rate of unemployment. In these models, a discretionary monetary policy causes a stabilization bias, i.e., a suboptimal response to shocks given that the central bank cannot affect the private sector's expectations. A discretionary monetary policy implies a more volatile process for inflation and the short-term interest rate than a commitment regime. In my model, this translates into larger movements in long-term interest rates which are strongly correlated with movements in the short rate. A central bank that can credibly commit does not need to move its instrument so much to control inflation, since it can effectively control the path of inflation by managing inflation expectations. In this case, even though policymakers still make errors estimating the natural rate, they react less to the perceived gap and misperceptions about the natural rate of unemployment become less important in the commitment regime. Given the volatility of long-term interest rates and their correlation with the short rate, my results show that a monetary regime under discretion is more likely to have prevailed in the U.S. since 1960.

Another related paper is Bikbov (2005). Like I, he stresses the importance of including term structure data to identify different monetary policy regimes. Bikbov models 
monetary policy as a forward-looking interest rate rule with monetary policy shocks. Allowing for switches in the parameters, he interprets periods with high variance in the monetary policy shock as discretionary regimes and periods with low variance as commitment regimes. Bikbov's results indicate that since the 1970s, monetary policy in the U.S. has continuously alternated between "active" versus "passive" policy regimes and between high versus low volatility monetary policy shocks. While Bikbov's results are suggestive, they are hard to interpret since he does not include optimal monetary policies of any kind in his analysis.

The model in this paper is a forward-looking model where the central bank cannot observe the shocks affecting the economy, in particular the natural rate of unemployment. Following the results in Orphanides and Williams (2002), I model policymakers' misperceptions of the natural rate of unemployment (the rate of unemployment consistent with stable inflation) as an autoregressive process. This has important implications for inflation, implications which are amplified in the case of discretionary monetary policy. When a policymaker cannot commit, he loses control over inflation expectations, and inflation and interest rate volatility are higher than when he can commit. In other words, under commitment the central bank anchors inflation expectations around its target and thus, expected future short-term rates and long-term rates move less. Under discretion, inflation expectations are much more volatile generating a larger volatility of long-term rates

In contrast to other papers that combine a macro model with no-arbitrage models of the term structure, ${ }^{1}$ I focus on a simple macro model and then explore the implications of different monetary regimes for long-term interest rates. This allows me to analyze the unresolved issue on how monetary policy has been conducted in the last 45 years. Certainly, the goal of the paper is not to construct a very precise model of the yield curve, but to find some linkages between macroeconomic fundamentals, monetary policy, and

\footnotetext{
${ }^{1}$ See, for instance, Bekaert et al. (2005), Hördahl et al. (2006) and Rudebusch and Wu (2008).
} 
the behavior of long-term rates. In particular, I want to calculate how much of the total volatility of long-term interest rates is explained by macro variables as opposed to financial risks. For this purpose, long-term interest rates are modelled by the expectation hypothesis.

To investigate the implications of the model, I estimate it using Bayesian methods. A large literature has documented a decline in business cycle volatility in the U.S. in the mid 1980s. Based on this evidence, I divide the data into two periods: 1960-1978 and 1983-2005 (excluding the four years at the beginning of the Volcker period when the Fed targeted nonborrowed reserves and the volatility of interest rates of all maturities increased dramatically). Despite the lower volatility of the macro fundamentals, the second period shows higher long-run interest rate volatility than the first period. In my model, this is attributed to a slightly larger estimated persistence in policymakers' misperceptions about the natural rate, which translates into more persistent inflation. Moreover, to explain the volatility of long-term interest rates in both periods, we need a lack of commitment from the monetary authority. Thus, the results indicate that U.S. monetary policy is best understood as originating from a discretionary regime.

To analyze the role of institutions in monetary policy, the paper also estimates the same model for two periods in the U.K., namely 1983-1997 and 1998-2005. In the latter period, the Bank of England became operationally independent. This exercise attempts to address the importance of central bank independence in the design of monetary policy. The U.K. evidence is different than the U.S. evidence. If anything, the post-independence monetary policy of the Bank of England has been closer to rules than discretion.

Last, I show that my results are also valid when the central bank and private sector have imperfect symmetric information and use optimal filters to update their information.

The rest of the paper is organized as follows. Section 2 describes the model. Sections 3 and 4 present the empirical evidence for the U.S. and the U.K., respectively. Section 
5 extends the model to the case of symmetric imperfect information and optimal filters. Section 6 concludes.

\section{The Model}

The model in this paper is a new Keynesian forward-looking model where firms have market power and get to adjust their prices with a fixed probability in each period. ${ }^{2}$

The loglinearized version of the Phillips curve and the expectations based IS curve are given by

$$
\pi_{t}=\beta E_{t} \pi_{t+1}-\theta\left(u_{t}-u_{t}^{N}\right)+\varepsilon_{t}
$$

and

$$
u_{t}=E_{t} u_{t+1}+\delta E_{t}\left(i_{t}-\pi_{t+1}\right)+\eta_{t},
$$

where $E_{t}(\cdot)$ denotes the rational expectations operator given the private sector information in period $t, \pi_{t}$ is the rate of inflation, $u_{t}$ the unemployment rate, and $u_{t}^{N}$ the natural rate of unemployment. The nominal interest rate, $i_{t}$, is the return on a shortterm instrument from period $t$ to $t+1, \eta_{t}$ is an exogenous demand shock assumed to be i.i.d. $N\left(0, \sigma_{\eta}^{2}\right)$, e.g. preference or government expenditure shocks, while $\varepsilon_{t}$ can be considered as an i.i.d. $N\left(0, \sigma_{\varepsilon}^{2}\right)$ markup shock, e.g. changes in sale taxes or in the degree of competition.

I assume that the natural rate of unemployment follows a first-order autoregressive process:

$$
u_{t}^{N}=\gamma u_{t-1}^{N}+\chi_{t}
$$

where $\chi_{t}$ is i.i.d. $N\left(0, \sigma_{\chi}^{2}\right)$ and the unconditional mean of $u_{t}^{N}$ is zero. ${ }^{3}$

A time-varying natural rate of unemployment is consistent with the substantial changes observed in U.S. unemployment in the last decades. Staiger et al. (1997) find

\footnotetext{
${ }^{2}$ See, for instance, Clarida et al. (1999) and Woodford (2003).

${ }^{3}$ In practice, I work with demeaned data, so all the variables have an unconditional mean of zero in the model.
} 
that the natural rate has fluctuated during the last 30 years in the U.S., and decreased by one percentage point between the 1980s and the mid 1990s. Shocks to the natural rate of unemployment could, e.g., be associated with exogenous changes in labor force demographics that affect labor supply.

It is important to mention two differences of the model from the standard new Keynesian literature. First, it is usually the case that equations (1) and (2) are expressed in terms of the output gap rather than the unemployment gap. However, I can write the model in terms of unemployment assuming that all employment variations occur in the extensive margin. ${ }^{4}$ Second, to be able to derive the model from first principles and have uncorrelated shocks, I write the IS curve in terms of unemployment and not in terms of the gap as it is usually done. ${ }^{5}$

\subsection{Information and the Natural Rate of Unemployment}

I assume that the private sector has complete information about the current state of the economy, while the policymaker knows the structural relations of the economy and the true parameter values, but conducts monetary policy under uncertainty about the shocks affecting the economy and, in particular, about $u_{t}^{N}$. This type of information asymmetry has been used in Svensson and Woodford (2004), Aoki (2003) and Primiceri (2006) and it is not relevant for the main argument of my paper. In Section 5 I extend the model allowing for symmetric imperfect information and show that the main results of the paper hold up in that case. However, as a benchmark, this simplification allows me to obtain simple and tractable analytical solutions providing a clear intuition for the transmission mechanisms in the model, and facilitates the estimation of the model.

\footnotetext{
${ }^{4}$ In particular, production is $Y_{t}=N_{t}^{\alpha}=\left(1-u_{t}\right)^{\alpha}$, where $N_{t}$ denotes the fraction of household members who are employed. Supply equations using unemployment gap have been used, for instance, in Blanchard and Gali (2006a), Blanchard and Gali (2006b), Primiceri (2006) and Reis (2003).

${ }^{5}$ Otherwise the shocks in equation (2) and equation (3) should be correlated. Moreover, I need to assume that changes in the natural rate are only due to changes in labor preferences and not to technology shocks.
} 
The importance of the natural rate of unemployment in choosing monetary policy follows from the effect on inflation of deviations of unemployment from its natural rate in equation (1). If the policymaker is unable to observe this gap, it may set interest rates higher or lower than optimal. As a result, misperceptions about the natural rate of unemployment can be costly in terms of stabilization performance. The private sector understands this fact when forming expectations about future inflation, and these inflationary expectations influence long-term interest rates.

Since this paper is a positive study seeking to explain the high volatility of long-term interest rates and to identify actual policy regimes, I do not define how the central bank filter its information, but assume instead that the gap between the actual natural rate, $u_{t}^{N}$, and the central bank estimate of the natural rate, $\widetilde{u}_{t}^{N}$, evolves according to

$$
\left(u_{t}^{N}-\widetilde{u}_{t}^{N}\right)=\rho\left(u_{t-1}^{N}-\widetilde{u}_{t-1}^{N}\right)+\xi_{t}
$$

where $\xi_{t}$ is assumed to be an i.i.d. $N\left(0, \sigma_{\xi}^{2}\right)$ misperception shock. In Section 5 I extend the model to show (for a calibrated example) that my main results hold up in the case when the central bank updates its information using optimal filters.

Orphanides and Williams (2002) empirically estimate a relationship like (4) and find that natural rate misperceptions are very persistent, independent of the filtering method. They calculate the gap as the difference between the retrospective estimates of the natural rate of unemployment (two-sided estimates) and the real time estimates (one-sided estimates) for six different estimation methods (four univariate filters and two multivariate unobserved-components models) which together give 36 alternative measures of natural rate misperceptions. They document a frequency distribution for $\rho$ with median 0.96 and a fifty percent confidence interval $(0.95,0.97)$, where the estimate of $\rho$ using the Kalman filter is 0.95 . They point out that equation (4) approximates several filtering methods and that the persistence of misperceptions is related to the nature of the filtering problem and does not necessarily imply that real-time estimates are inefficient: even using efficiently all available macroeconomic data, misperceptions 
about the natural rate are very persistent. Note that the size of the estimation errors is not essential for the argument of my paper, but the fact that they are very persistent.

\subsection{Optimal Monetary Policy}

To close the model, I study optimal monetary policy under discretion and commitment, where the instrument of monetary policy is the nominal interest rate, $i_{t}$. In each period, policymakers set the optimal policy after forming their beliefs about the natural rate of unemployment according to equation (4).

Under discretion, the central bank chooses the optimal nominal interest rate in each period, without any binding commitment to future actions. The private sector understands that the monetary authority cannot resist the temptation to exploit the short-run trade off between inflation and unemployment and hence, the central bank cannot influence private sector expectations. When maximizing, the monetary authority therefore takes future expectations as given.

Under commitment, the central bank has the ability to bind its future actions to follow an optimal state-contingent rule for the nominal interest rate, conditional upon the shocks arising in any period. In this case, the central bank can exploit its influence on private sector expectations for the entire future to stabilize the economy.

The central bank sets its policy instrument $i_{t}$, to minimize

$$
\widetilde{E}_{t} \sum_{i=0}^{\infty} \beta^{i}\left[\pi_{t+i}^{2}+\lambda\left(u_{t+i}-u_{t+i}^{N}\right)^{2}\right],
$$

subject to equations (1)-(2), and where $\widetilde{E}_{t}(\cdot)$ denotes the expectation operator given the central bank information set in period $t .{ }^{6}$ In particular, $\widetilde{E}_{t} u_{t}^{N}=\widetilde{u}_{t}^{N}$ given that the central bank cannot observe $u_{t}^{N}$. This loss function penalizes deviations of inflation and unemployment from their targets, where the inflation target is normalized to zero. ${ }^{7}$

\footnotetext{
${ }^{6}$ Only in the case of optimal filters is $\widetilde{E}_{t}(\cdot)$ the rational expectation operator.

7 The rationales for these costs are that inflation volatility is costly because it induces an inefficient
} 
The first-order conditions of this problem under discretion imply ${ }^{8}$

$$
\pi_{t}=\frac{\lambda}{\theta}\left(u_{t}-\widetilde{u}_{t}^{N}\right)
$$

Using this result in equation (1) and performing repeated substitutions, the equilibrium outcome for inflation in the discretionary case is

$$
\pi_{t}=\frac{\lambda \theta}{\lambda+\theta^{2}-\beta \lambda \rho}\left(u_{t}^{N}-\widetilde{u}_{t}^{N}\right)+\frac{\lambda}{\lambda+\theta^{2}} \varepsilon_{t} .
$$

This last equation shows that when the central bank estimate of the natural rate of unemployment differs from the real value, there is an inflation bias only in the sense that inflation will be different from its target. Note that the model does not have a conventional (Kydland and Prescott (1977), Barro and Gordon (1983)) inflation (level) bias. The existence of such a bias is not essential for the argument in this paper. What is essential, however, is that the policymaker loses control over private expectations in a discretionary policy regime.

Inflation expectations evolve as

$$
E_{t} \pi_{t+i}=\frac{\lambda \theta}{\lambda+\theta^{2}-\beta \lambda \rho} \rho^{i}\left(u_{t}^{N}-\widetilde{u}_{t}^{N}\right) .
$$

As a result, when the natural rate of unemployment is higher (lower) than the central bank's estimate, there is a persistent rise (fall) in inflation. ${ }^{9}$ The intuition is that when the monetary authority underestimates the natural rate of unemployment, it sets the interest rate so as to achieve a higher inflation than the target in order to reduce the

allocation of resources, while unemployment volatility is costly for risk averse households. In practice, since I work with demeaned data, the inflation target is equal to the mean of inflation in each period.

${ }^{8}$ I assume that the central bank can achieve the first-order condition, but I do not specify how this is done. Conditional on a specific theory for how the central bank updates its information, we could derive an explicit mapping from observable variables to the interest rate. I take a more general stand and assume that the central bank $(i)$ can attain its first-order condition, Equation (5), ( $i i)$ updates its information such that Equation (4) holds.

9 Some authors have used this argument to explain the stagflation episode in the 1970s. See, for instance, Orphanides and Williams (2002), Primiceri (2006) and Reis (2003). 
perceived unemployment gap. Since misperceptions about the natural rate of unemployment are persistent (high values of $\rho$ ), this raises expectations of future inflation (and thereby long-term interest rates).

This last equation shows that inflation expectations are different from its (zero) target when there are estimation errors. An alternative approach used in the literature to introduce persistent deviations of inflation from its target, is to have a time-varying inflation target. In that case, to generate volatility in long-term rates one should assume that the monetary policy constantly changes its target. From a theoretical and empirical point of view that is a very implausible explanation. As opposed to policy preferences, my explanation is based on the undeniable fact that the central bank has to estimate a time-varying natural rate using historical data, and in doing so, it makes estimation errors.

I assume optimal monetary policy under commitment to be a timeless perspective policy. Moreover, to simplify the problem, I assume that the central bank does not revise its estimates of the natural rate of unemployment in the next period, so $\widetilde{E}_{t} u_{t}^{N}=$ $\widetilde{E}_{t+1} u_{t}^{N}=\widetilde{u}_{t}^{N} \cdot{ }^{10}$ In Section 5 I drop this assumption.

The first-order conditions of the central bank under commitment imply

$$
\pi_{t}=\frac{\lambda}{\theta}\left(u_{t}-\widetilde{u}_{t}^{N}\right)-\frac{\lambda}{\theta}\left(u_{t-1}-\widetilde{u}_{t-1}^{N}\right)
$$

It can be shown that for given parameters, inflation reacts less to markup and misperception shocks in the commitment case than in the discretionary case. The reason is that the monetary authority can control future expectations under commitment and thus, the behavior of inflation today: if the private sector expects lower future inflation then inflation becomes lower already today.

In the full information case, the dynamic feature of the model introduces a stabilization bias, in that unemployment is overstabilized and inflation volatility is higher

\footnotetext{
${ }^{10}$ In the data, the difference between $\widetilde{E}_{t} u_{t}^{N}$ and $\widetilde{E}_{t+1} u_{t}^{N}$ is indeed very small.
} 
under discretion. However, in my model, the volatility of unemployment turns out to be similar in both regimes. But the presence of the second term in equation (6) makes the inflation rate less persistent than in equation (5).

Orphanides and Williams (2002) show that when the policymaker adopts policy rules ignoring the misperceptions regarding the natural rate of unemployment, this is costly in terms of inflation and unemployment stabilization. In my model, misperceptions also translate into long-term interest rate volatility.

\subsection{Expectation Hypothesis of the Yield Curve}

To calculate long-term interest rates, I use the expectation hypothesis of interest rates, which establishes a relationship between long-term interest rates and short rates. According to the expectation hypothesis, the interest rate on a discount bond of maturity $m$ at time $t$ should be equal to the expected average of future short interest rates over the same period, plus a term premium:

$$
i_{t}^{m}=\frac{1}{m}\left[i_{t}+i_{t+1 \mid t}+i_{t+2 \mid t}+\ldots+i_{t+m-1 \mid t}\right]+\tau_{t}^{m},
$$

where $i_{t+m \mid t}=E_{t}\left(i_{t+m}\right)$ and I added an i.i.d. $N\left(0, \sigma_{m}^{2}\right)$ term premium shock. A timevarying term premium is inconsistent with a first-order loglinear approximation of the new Keynesian macro-model. However, following some of the macro-finance literature (e.g. Hördahl et al. (2006) and Rudebusch and Wu (2008)), I allow for exogenous (finance oriented) deviations of the pure expectation hypothesis.

Even though the empirical evidence on the relevance of the expectation hypothesis is mixed, it is often used in formal macroeconomic analysis. Fuhrer (1996) finds that changes in monetary policy regimes can account for most of the empirical failure of the expectation hypothesis. Given that I study two time periods when monetary policy may have been stable, the use of the expectation hypothesis may be a good approximation. Moreover, among the papers rejecting the expectation hypothesis, some fail to reject it 
at the long end of the yield curve, which is the main focus in this paper. ${ }^{11}$

\subsection{Solution Method}

Given the asymmetry in the information set of the central bank and the private sector, optimal control methods, as those described in Söderlind (1999), cannot be applied here. However, equations (1)-(4) and the first-order condition of the monetary authority (equation (5) or (6)) form a system of difference equations that can be solved using the methods described in Sims (2002). Moreover, since $i_{t}^{m}$ does not enter the first five equations of the model, I use this solution to solve for long-term interest rates using equation (7). Once the model is solved and expressed in state-space form, the likelihood of given parameters can be computed using the Kalman filter.

\section{Empirical Evidence for the U.S.}

The model is estimated using Bayesian methods. I use Markov Chain Monte Carlo (MCMC) simulation methods to obtain the posterior distribution of the parameters. The posterior output can then be used to compute any posterior function of the parameters: impulse responses, moments, etc. For each model, two MCMC chains were simulated with 50,000 draws each and a burn-in period of 10,000 draws.

Five quarterly U.S. macro data series are used in the estimation: unemployment, inflation, short-term nominal interest rate and Treasury securities at five and ten years between 1960Q1-2005Q4. ${ }^{12}$ All series were demeaned.

As mentioned earlier, I divide the data into two periods, from 1960Q1 to 1978Q4 and

\footnotetext{
11 See, for instance, Campbell and Shiller (1991) and Sarno et al. (2007).

12 The data on unemployment is seasonally adjusted data from the Bureau of Labor Statistics (BLS). The nominal interest rate is the quarterly Federal Funds Rate, and inflation is calculated as the change in the seasonally adjusted GDP deflator obtained from the Bureau of Economic Analysis (BEA). Longterm interest rates are quarterly market yields on U.S. Treasury securities at five and ten years constant maturity obtained from the Federal Reserve Board.
} 
1983Q1 to 2005Q4, excluding the Volcker nonborrowed reserves target period (when the volatility of interest rates at all maturities increased dramatically). Many studies have pointed out that these two periods have different characteristics in monetary policy and/or business cycles volatility. ${ }^{13}$ Figure 1 clearly shows a break in volatility in the early 1980s. Table 1 shows that the standard deviation of inflation and unemployment has indeed decreased in the second period. Even though inflation volatility is lower in the second period, interest rates at all maturities are more volatile.

Estimating the model for each policy regime separately overcomes the problem of unstable nonpolicy parameters across different regimes. In other words, if one thinks that monetary policy has changed across the two subperiods and affected private sector behavior, this is not a major problem because I assume the parameters to be constant only within each subperiod.

The prior distributions of the parameters are presented in Table 2. All standard deviations have a gamma distribution with mode 0.10 and a standard error of 0.05 . The persistence in the natural rate of unemployment, $\gamma$, is beta distributed with mode 0.95 and a standard error of 0.02 . In general, there is agreement among economists that the natural rate of unemployment is highly persistent, close to a unit root process. The weight on output gap in the central bank loss function, $\lambda$, is normally distributed with mode 1 and standard error $0.20 .{ }^{14}$ The slope coefficient in the Phillips curve, $\theta$, is gamma distributed with mode 0.10 and standard error 0.02. This is approximately equivalent to the value estimated by Orphanides and Williams (2002) and Rudebusch (2002) using survey data as proxies for inflation expectations.

One prior that deserves special attention is the persistence in misperceptions, $\rho$, which is beta distributed with mode 0.95 and standard error 0.005 . I set a very tight prior on

\footnotetext{
13 See, for instance, Boivin and Giannoni (2006), Clarida et al. (2000), Cogley and Sargent (2005) and Sims and Zha (2006).

14 The prior for $\lambda$ is higher than the values commonly used in the literature. However, when I estimate the model with a flat prior for $\lambda$, the model prefers values of $\lambda$ greater than one (or around one). This is robust to different priors for the shocks and estimating the model without long-term rates.
} 
this parameter to rule out cases where $\rho$ is close to one, meaning that misperceptions never die out. Naturally, misperceptions can still be very persistent. Moreover, in Section 5 I show that even using the Kalman filter to estimate the natural rate delivers values of $\rho$ close to 0.95 . In particular, a value of $\rho$ equal to 0.95 implies that the half-life of a shock is three years and one quarter. As previously mentioned, the high persistence in misperceptions is documented in Orphanides and Williams (2002). Alternatively, I could have fixed this parameter, but allowing for some flexibility seems a better solution since, as I will show later, my results are very sensitive to this parameter.

As is common practice, I fix the value of the discount factor, $\beta$, at 0.99 , which corresponds to an annual steady state real rate of four percent. Finally, the value of the slope parameter in the IS-curve, $\delta$, was pre-set at 0.5 , corresponding to a degree of risk aversion equal to two and a linear production function.

\subsection{Estimation Results}

Before going into the main results of the paper, I discuss the general properties of my estimation results. Tables 2 and 3 report the mean and the 5 th and 95 th percentile of the posterior distribution of the parameters under alternative monetary policy regimes. ${ }^{15}$

A first thing to notice is that most of the estimates are robust to the monetary policy regime. However, the posterior mean of the standard deviation of misperception shocks, $\sigma_{\xi}$, and the weight on the unemployment gap in the central bank loss function, $\lambda$, are higher in the commitment case. Higher values of these parameters imply a larger impact of misperceptions and thus, higher volatility in the data (especially long-term rates). This is important because, as discussed below, the commitment regime has difficulties in replicating the volatility of long-term rates observed in the data. In the same way, the variances of term premium shocks are larger in the commitment case.

\footnotetext{
${ }^{15}$ Convergence to a stationary distribution was monitored computing the potential scale reduction for all parameters, as described in Gelman et al. (2004), and plotting the path of the different parameters along the chain.
} 
In accordance with most estimates in the literature, both the natural rate of unemployment and misperceptions about this variable exhibit a high degree of persistence in both regimes. The slope coefficient in the Phillips curve, $\theta$, is stable across time and also similar to other estimates in the literature, although considerably lower in the commitment case.

One slightly puzzling result is that the variance of markup shocks across regimes is larger in the second period. This result is in contrast to the common perception that certain supply shocks, e.g. oil shocks, were larger in the 1970s. The estimates also show that the variance of shocks to the natural rate of unemployment has been lower in the second period. One explanation for this time pattern is the productivity slowdown. Last, the estimates of $\sigma_{\eta}$, the variability of demand shocks, are also lower in the second period. This result is in line with Gordon (2005) who provides some evidence for smaller demand shocks after 1984 due to a reduced volatility of Federal government spending, residential housing and inventory change.

\subsection{Macroeconomic Variables and Monetary Policy Regimes}

Figures 2 and 3 show the posterior predictive distribution of the standard deviation of unemployment, inflation and the short-term interest rate. ${ }^{16}$ A first look at the graphs indicates that in the first period, both regimes replicate the observed volatility in the data reasonably well, specially considering how simple the model is.

In the second period, however, both regimes have problems replicating the volatility of unemployment and inflation, while a discretionary regime matches the volatility of the short-term interest rate much better. The model's inability to match the volatility of inflation in the second period is related to the high estimates of the variance of markup shocks, which seem at odds with the data.

\footnotetext{
16 The posterior density was computed using a kernel smoothing method, for a sample of 200 simulations for 75 periods from 500 draws of the posterior. To avoid autocorrelation, the draws from the posterior were picked in fixed intervals.
} 
Overall, and in line with the common view in the literature, it is not easy to distinguish between alternative monetary policy regimes by only looking at the volatility of the macro variables.

\subsection{Long-Term Rates and Monetary Policy Regimes}

\subsubsection{Variance Decomposition}

Both monetary policy regimes can explain a large part of the volatility of long-term interest rates, since the term premium shock, the residual in equation (7), will capture a great deal of the variation not explained by the macro model. However, the relative sources of interest rate volatility differ across monetary regimes.

The variance decomposition of inflation, the short interest rate and long-term interest rates at different horizons are shown in Tables 4 and 5. Misperception shocks that feed into monetary policy account for a large share of the variation in long-term rates in a model under discretion. At a 10 year horizon, misperception shocks explain $87 \%$ of the variation in long-term rates in the first sub-sample and $96 \%$ in the second.

In the commitment regime, the variation in ten-year interest rates is instead predominantly explained by term premium shocks. After ten years, term premium shocks explain $45 \%$ of the variation in long-term rates in the first sub-sample and $88 \%$ in the second. Hence, if we want to attribute some of the variation in long-term rates to macroeconomic fundamentals, rather than to residual variation in time-varying term premiums, a monetary policy regime under discretion provides a better explanation for the volatility puzzle. Moreover, this implies that the expectation hypothesis of interest rates allows us to account for most of the observed long-term interest rate volatility when the central bank acts under discretion. 


\subsubsection{Switching off Term Premium Shocks}

To further investigate how much of the total volatility of long-term interest rates is explained by macro variables, as opposed to financial risks, I once more simulate the model, but switch off the term-premium shocks. This allows me to isolate the effect of macro variables in explaining the volatility of long-term rates. Figure 4 shows the posterior predictive distribution of the standard deviation of the ten-year long-term interest rate implied by the model, both with and without time-varying term premiums. The left-hand panels in the figure show that the model under discretion can better explain the volatility of the long-term interest rate and can replicate a large part of the volatility observed in the data, especially during the second period. The main features of the model driving this result are policymakers' autocorrelated misperceptions about the natural rate of unemployment and a discretionary monetary policy. Together, these translate into a very persistent inflation response and volatile long-term rates: since inflation in the future is positively correlated with inflation today, a shock to inflation will affect expectations of future inflation and future short-rates, and through equation (7) will have a direct effect on long-term rates. There is a direct link between monetary policy regimes and long-term rates volatility: under commitment the central bank anchors inflation expectations around its target and thus expected future short-term rates are also closer to their target. This translates into smoother long-term rates. Under discretion, inflation expectations are much more volatile generating a larger volatility of long-term rates.

It is important to mention that even in the case with term premium shocks, the model underpredicts the volatility in the data. The reason for that is that a large share of the variance is unlikely to be explained without a level factor, which captures parallel movements in the level of the whole yield curve. ${ }^{17}$ Empirically, the level factor

\footnotetext{
17 To address this problem, I also estimate the model using linearly detrended data. The results are in general the same as before. However, a better alternative would be to detrend the data using estimates of the level factor obtained from the finance literature.
} 
of the yield curve has been associated with long-run expected inflation. One way of introducing a level factor in the model would be to introduce a random walk inflation target or sporadic shifts in the long-run policy target for inflation (shifting endpoints). Kozicki and Tinsley (2001) reject the random walk hypothesis and link endpoint shifts to agents learning about sporadic shifts in long-term policy goals.

Figure 4 also shows that U.S. interest rates were more volatile in the second period than in the first. In the model, there is also an increase in bonds volatility; there is a shift to the right in the posterior predictive distribution of long rates in the second period. This is due to a slightly larger estimate of the persistence in misperceptions. Interestingly, when I independently calculate the difference between one- and two-sided estimates of the natural rate of unemployment using univariate filters, I also find an increase in the autocorrelation coefficient in the second period.

Moreover, the model is also able to explain bond returns volatility. Table 6 reports the simulated volatility in bond returns implied by the model when term premiums are switched off, and where the volatility of bond returns is defined as the standard deviation of the quarter-to-quarter change in long-term interest rates. ${ }^{18}$ Once more, a monetary regime under discretion appears to more closely replicate the data. The table also shows an increase in bond returns volatility in the second period, both in the model and in the data. As mentioned before, in the model this is caused by a slightly higher persistence in policymakers' misperceptions.

\subsubsection{Correlations with Short-term Interest Rate}

As shown in Table 1, short- and long-term interest rates are positively correlated. Figures 5 and 6 show posterior distributions of the correlation coefficient between the short-term interest rate and the other variables in the model. As in the case of volatility,

\footnotetext{
18 The return on a bond of maturity $m$ is $\ln \left(\frac{P_{t}^{m}}{P_{t-1}^{m}}\right) \simeq-m\left(i_{t}^{m}-i_{t-1}^{m}\right)$, where $P_{t}^{m}=\exp \left(-i_{t}^{m} m\right)$ is the price of the zero coupon bond.
} 
the model under discretion fits the data better. In particular, the discretionary regime can replicate the high positive correlation between short- and long-term interest rates observed in the data, while the commitment regime fails in this regard.

The model can also explain another puzzling observation. In the real world, longterm interest rates typically move in the same direction as the short rate. However, during certain episodes, they move in the opposite direction. In the model, this can happen when the economy is simultaneously hit by a negative demand shock and a positive misperception shock. In that particular case, nominal long-term rates move up because of the positive misperception shock, since this will have a positive effect on future inflation. On the other hand, the movement in the short rate is determined by the relative size of the two shocks. When demand shocks are sufficiently large to offset misperception shocks, the short rate goes down to prevent a higher unemployment rate.

\subsubsection{Monetary Policy Regimes}

Finally, let us explicitly consider the second issue motivating the paper, namely the debate about monetary policy regimes. The model I estimate uses long-term interest rate data to empirically distinguish between different monetary policy regimes. Given the results already discussed in this section, it should be clear that a monetary regime under discretion is more likely to have prevailed in the U.S. In the data, we observe long rates to be highly volatile and correlated with the short rate. The results generated by the model seem to preclude a regime where the central bank can commit to future actions and stabilize inflation expectations. It seems that market participants believed and behaved as if the monetary policy followed by the Fed were discretionary during the whole sample. Moreover, the different chairmen of the Fed do not seem to have influenced those beliefs. In this way, long-term interest rates can help us understand how monetary policy has been conducted in the last 45 years.

This result is formally confirmed if we use posterior odds ratios to compare the two 
policy regimes. Table 7 shows that the posterior odds ratios clearly favor the discretionary regime in both periods. ${ }^{19}$ Similarly to my previous observations, this result is starker in the second period.

A discretionary monetary policy implies a more volatile process for inflation and the short-term interest rate than a commitment regime. In the model, this translates into larger movements in long-term interest rates which are strongly correlated with movements in the short rate. A central bank that can credibly commit does not need to move its instrument so much to control inflation, since it can effectively control the path of inflation by managing inflation expectations. In this case, even though policymakers still make errors estimating the natural rate, they react less to the perceived gap and misperceptions about the natural rate of unemployment become less important than in the discretionary regime.

\subsubsection{Model Assessment}

In the previous subsections, I have shown that the variability of long-term interest rates may be due to a combination of lack of knowledge about the natural rate of unemployment and monetary policy regimes. Next, I investigate the marginal contribution of these factors to explain long-term rate volatility. I graphically do so for the case when risk premium shocks are shut off. Figure 7 shows the standard deviation of 10-year interest rates in the U.S. between 1983 and 2005 to be 2.26. The figure also shows the posterior predictive distribution for the discretionary and commitment case (as in Figure 4 ), and the simulated standard deviation in the case when the monetary authority can directly observe $u_{t}^{N}$ : when misperception shocks are shut off. ${ }^{20}$ The two lines to the left show that the simulated volatility in a model where the central bank can observe $u_{t}^{N}$

\footnotetext{
19 The posterior odds ratio also favors the discretionary regime as compared to a model with a Taylor-type interest rate rule $i_{t}=\tau i_{t-1}+(1-\tau)\left[E_{t} \pi_{t+1}-\varphi / 4\left(u_{t}-\widetilde{u}_{t}^{N}\right)\right]$.

${ }^{20}$ I simulate the standard deviation of 10 -year interest rates under discretion and commitment using the estimated posterior mean and setting the variance of misperception shocks equal to zero.
} 
is very low and far from the data, independently of the monetary policy regime. Once we allow for imperfect information about the natural rate of unemployment, the model under discretion outperforms the commitment case and is able to explain most of the observed volatility in the data.

Subsequently, I ask how important is the value of $\rho$ for explaining movements in long-term rates. Figure 8 shows that only high values of $\rho$ can add volatility to longterm interest rates. Using the posterior mean of the other parameters for the period 1983-2005, the figure simulates the volatility of 10 year rates for different values of $\rho$ under discretion. ${ }^{21}$ In accordance with Table 3, values of $\rho$ of around 0.98 are able to explain the observed volatility in the data. Furthermore, very little volatility can be explained when misperception shocks are not very persistent: when $\rho$ is below 0.85 , the model is not able to add volatility to long-term rates. In the commitment case, even for values of $\rho=1$, the model generates a maximum of 165 basis point of volatility.

\section{The Case of the U.K.}

A large literature has studied the relation between monetary institutions and credibility. ${ }^{22}$ In particular, many papers stress the fact that independent central banks with price stability as their main objective will increase credibility and stabilize inflation without much effect on output or unemployment. ${ }^{23}$

In May 1997, the Bank of England was officially granted operational independence. Since then, the bank is committed to promoting and maintaining monetary and financial stability as its contribution to a healthy economy. Given the specific inflation target objective of the bank, one may think that monetary policy can be approximated by a commitment regime to achieve this goal.

\footnotetext{
${ }^{21}$ For a sample of 1,000 simulations for 75 periods.

22 See Persson and Tabellini (2000) for a review.

23 Alesina and Summers (1993), among others, find that a more independent central bank reduces the level and variability of inflation, but has not impact on real activity.
} 
A first look at the data shows that after the Bank of England became independent, U.K. data is indeed less volatile both when it comes to inflation and unemployment. Table 8 shows that the volatility of short and long rates in the U.K. during the independence period has been lower than in earlier periods. The table also includes data for the U.S. over the same two periods. Clearly, the volatility in long-term rates fell proportionally more in the U.K. than in the U.S. To investigate whether this downward shift in volatility can be attributed to a change of monetary regime, I estimate the model under discretion and commitment for U.K. data during the periods 1983-1997 and 1998-2005. ${ }^{24}$

\subsection{Estimation Results for the U.K.}

In the estimation, I use the same priors as for the U.S. Table 9 reports the estimated mean of the parameters for the U.K. The results are in general similar to those in the U.S.: high persistence of the natural rate of unemployment and the misperceptions of the central bank, a weight on the unemployment gap in the central bank loss function greater than one, and a response of inflation to the unemployment gap close to 0.08 .

\subsection{Implications of Different Monetary Policy Regimes}

Results not reported here show that both regimes replicate the observed volatility in the macro data reasonably well in both periods. One interesting issue is that after 1997, the correlation between inflation and the short-term interest rate becomes negative in the U.K. (see Table 8). Figure 9 shows that this can only be replicated by the commitment regime. ${ }^{25}$ However, the discretionary regime does better in replicating the correlation of the short-term and the long-term rate.

Figure 10 reports the posterior predictive distribution of the standard deviation of

\footnotetext{
24 The data was obtained from the OECD database on unemployment, short-term interest rate (threemonths Treasury bill), GDP deflator and ten-year government bond yields. All series were demeaned.

25 For the U.S., none of the regimes replicates the negative correlation between inflation and the short-term rate observed in the data.
} 
the ten-year rate implied by the model, with and without time-varying term premiums, before and after 1998. The figure shows that the discretionary regime does better in replicating the volatility of long-term rates before 1998, even if we add term-premium shocks. However, after 1998, the commitment regime is closer to replicating the observed volatility. Moreover, a variance-decomposition analysis for the U.K. after 1998 shows that term premium shocks have a large role in explaining the volatility of long-term rates in both regimes. ${ }^{26}$ Rephrasing, term-premium shocks are now an important component of long-term rate volatility in the U.K., independently of the monetary policy regime. This indicates that we only need to add a small amount of variable term premiums to the model, for the commitment regime to do well in replicating the volatility of long-term rates.

Last, Table 10 formally shows that the posterior odds ratio decisively prefers the discretionary regime before 1998. However, after 1998, we cannot longer reject the commitment regime in favor of the discretionary regime; in fact, there is slight evidence in favor of the former. ${ }^{27}$ If anything, the evidence suggests that once the Bank of England gained independence, its monetary policy regime became closer to rules than discretion.

\section{The Case of Imperfect Symmetric Information and Optimal Filters}

In this section I show that the basic results of the paper hold up when both the central bank and the private sector have imperfect information and use optimal filters to extract information about the natural rate. Differently from the model in Section 2, the private sector has the same information than the central bank: both of them are

\footnotetext{
${ }^{26}$ At a 10 year horizon, term premium shocks explain one fourth of the variation in long-term rates in the discretionary regime and three fourths in the commitment case.

${ }^{27}$ In the case of the U.S. during the same period, and despite the lower volatility of long-term interest rates, the posterior odds ratio still favors the discretionary regime after 1998.
} 
unable to observe the shocks affecting the economy. Moreover, I disregard equation (4) and assume that to form expectations and estimate the natural rate, all the agents in the economy filter the data in the most efficient way. More specifically, I follow the work of Svensson and Woodford (2003) who derive the optimal weights on indicators in models with symmetric partial information. ${ }^{28}$

The structure of the model is similar to that in Section 2, but now the central bank and the private sector use the Kalman filter to infer $u_{t}^{N}$ and the other shocks affecting the economy. To generate a well-defined signal extraction problem, I assume that the markup shock in equation (1) follows a first-order autoregressive process $\varepsilon_{t}=\omega \varepsilon_{t-1}+\varphi_{t}$, where $\varphi_{t}$ is assumed to be i.i.d. $N\left(0, \sigma_{\varphi}^{2}\right)$. Moreover, to improve the empirical fit of the model, I follow the literature and allow for endogenous persistence in inflation assuming full indexation to past inflation. I can then write equation (1) as

$$
\pi_{t}=\frac{1}{1+\beta} \pi_{t-1}+\frac{\beta}{1+\beta} E_{t} \pi_{t+1}-\theta\left(u_{t}-u_{t}^{N}\right)+\varepsilon_{t} .
$$

I calibrate the model for the commitment and discretionary case using the estimated posterior means for the U.S. between 1960-1978 as reported in Table 2. I set $\omega$ equal to 0.85 and $\sigma_{\varphi}$ equal to 0.17 . These values imply an unconditional standard deviation for $\varepsilon$ of 0.32 , which is approximately the estimated mean value reported in Table 2 .

Table 11 shows that in the case of imperfect symmetric information, the discretionary regime better replicates the volatility of long-term interest rates. The model under discretion generates twice as much volatility in long-term rates as the commitment regime. Overall, the simulated data is consistent with the evidence presented in Figure 4 (left upper panel): in that figure, I not only show the mean but the whole distribution, which strengths the argument that the discretionary regime better replicates the volatility of long-term rates.

This example shows that the main results of my paper still hold in the extreme case of optimal filtering and symmetric imperfect information: in the commitment regime, the

\footnotetext{
${ }^{28}$ For a detailed description of the solution, see Svensson and Woodford (2003).
} 
model can not explain much of the puzzle under plausible parameters values. Moreover, the model generates to high inflation volatility in the commitment case. However, the simulated volatility of unemployment is too low, specially in the discretionary regime. One can argue that the model is too simple in this respect, and introducing habits in the model can help to better match the properties of unemployment.

Last, the last row in Table 11 reports the simulated implied values for $\rho$ in equation (4). As shown by Orphanides and Williams (2002), misperceptions about the natural rate of unemployment are very persistent even when the monetary authority uses an optimal filter. In both regimes, the mean simulated value of $\rho$ is 0.95 , supporting my choice of equation (4) in Section 2 and the prior used for this parameter.

\section{Conclusions}

This paper attempts to explain the behavior of long-term U.S. interest rates in the last 45 years from a macroeconomic perspective. Most papers in the literature rely on a time-varying inflation target to explain the volatility of long-term rates. I propose an alternative explanation and show that the high volatility observed in long-term yields and their correlation with the short rate may be due to a combination of quite persistent estimation errors about the natural rate of unemployment and a discretionary monetary policy. In a discretionary regime, the policymaker loses control over inflation expectations and actual inflation. Persistent misperceptions that feed into policy make inflationary expectations quite volatile, which has an effect on the volatility of long-term rates and their correlation with the short rate. For this reason, incorporating yield-curve data in the analysis makes it possible to empirically distinguish between different monetary policy regimes.

To further analyze the role of different institutions in monetary policy, the paper estimates the same model with U.K. data during 1983-1997 and 1998-2005, the latter 
being a period during which the Bank of England was operationally independent. Evidence suggests that during the independence period, the policy pursued by the Bank of England can equally well be classified as a commitment regime or a discretionary regime.

If there are benefits from stabilizing inflation expectations and bonds volatility, the paper has some normative implications. In particular, providing a commitment technology for the monetary authority can reduce the costs of a discretionary regime. Moreover, reaction functions for the central bank that do not respond to the natural rate of unemployment will avoid the problem of policymakers' misperceptions. ${ }^{29}$

Last, it is important to mention that the model is not able to explain all the volatility in long-term rates. Other reasons such as changing preferences of the central bank could also contribute to explain the data. As previously mentioned, it would be interesting to study the case when shifts in long-term policy goals occur sporadically. However the main point of the paper is that less of the puzzle remains once one takes into account the undeniable fact that the central bank has to estimate the natural rate using historical data. As opposed to policy preferences, my explanation is based on something observable, or at least something that can independently be estimated: persistent changes in the natural rate.

\section{References}

Alesina, A. and Summers, L. (1993). Central bank independence and macroeconomic performance: Some comparative evidence. Journal of Money, Credit, and Banking, 25(2):151-162.

Alexius, A. and Welz, P. (2005). Can a time-varying equilibrium real interest rate explain the excess sensitivity puzzle? Mansucript.

\footnotetext{
${ }^{29}$ Orphanides and Williams (2002) suggest, for instance, that the monetary authority could react to unemployment growth instead of the unemployment gap.
} 
Aoki, K. (2003). On the optimal monetary policy response to noisy indicators. Journal of Monetary Economics, 50:501-523.

Barro, R. and Gordon, D. (1983). A positive theory of monetary policy in a natural rate model. Journal of Political Economy, 91(4):589-610.

Baxter, M. (1988). Toward an empirical assessment of game-theoretic models of policymaking: A comment. Carnegie-Rochester Conference Series on Public Policy, 28:141152.

Beechey, M. (2006). Exess sensitivity and volatility of long interest rates: The role of limited information in bond markets. Sveriges Riksbank, Working Paper 173.

Bekaert, G., Cho, S., and Moreno, A. (2005). New-keynesian macroeconomics and the term structure. NBER, Working Paper 11340.

Bikbov, R. (2005). Monetary policy regimes and the term structure of interest rates. Manuscript.

Blanchard, O. and Gali, J. (2006a). A new keynesian model with unemployment. Manuscript.

Blanchard, O. and Gali, J. (2006b). Real wage rigidities and the new keynesian model. Manuscript.

Boivin, J. and Giannoni, M. (2006). Has monetary policy become more effective? Review of Economic and Statistics, 88(3):445-462.

Campbell, J. Y. and Shiller, R. (1991). Yield spreads and interest rate movements: A bird's eye view. Review of Economic Studies, pages 495-514.

Christiano, L. J. and Fitzgerald, T. (2003). Inflation and monetary policy in the twentieth century. Economic Perspectives, Federal Reserve Bank of Chicago, 1Q:22-45. 
Clarida, R., Gali, J., and Gertler, M. (1999). The science of monetary policy: A new keynesian perspective. Journal of Economic Literature, 37(4):1661-1707.

Clarida, R., Gali, J., and Gertler, M. (2000). Monetary policy rules and macroeconomic stability: Evidence and some theory. Quarterly Journal of Economics, 115(1):147-80.

Cogley, T. and Sargent, T. J. (2005). Drifts and volatilities: Monetary policies and outcomes in the post WWII U.S. Review of Economic Dynamics, 8:262-302.

Cook, T. and Hahn, T. (1989). The effect of changes in the federal funds rate target on market interest rates in the 1970s. Journal of Monetary Economics, 24(3):331-351.

Ellingsen, T. and Söderström, U. (2001). Monetary policy and market interest rates. American Economic Review, 91(5):1594-1607.

Ellingsen, T. and Söderström, U. (2005). Why are long rates sensitive to monetary policy. Manuscript.

Fuhrer, J. (1996). Monetary policy shifts and long-term interest rates. Quarterly Journal of Economics, 111(4):1183-1209.

Gelman, A., Carlin, J. B., Stern, H. S., and Rubin, D. B. (2004). Bayesian Data Analysis. Chapman and Hall/CRC, second edition.

Gordon, R. (2005). What caused the decline in u.s. business cycle volatility? NBER, Working Paper 11777.

Gürkaynak, R., Sack, B., and Swanson, E. (2005). The sensitivity of long-term interest rates to economic news: Evidence and implications for macroeconomic models. American Economic Review, 95(1):425-436.

Hördahl, P., Tristani, O., and Vestin, D. (2006). A joint econometric model of macroeconomic and term-structure dynamics. Journal of Econometrics, (131):405-444. 
Hördahl, P., Tristani, O., and Vestin, D. (2008). The yield curve and macroeconomic dynamics. Economic Journal (forthcoming).

Ireland, P. N. (1999). Does the time-consistency problem explain the behavior of inflation in the united states. Journal of Monetary Economics, 44:279-291.

Kozicki, S. and Tinsley, P. (2001). Shifting endpoints in the term structure of interest rates. Journal of Monetary Economics, 47:613-652.

Kydland, F. and Prescott, E. (1977). Rules rather than discretion: The inconsistency of optimal plans. Journal of Political Economic, 85(3):473-492.

Orphanides, A. and Williams, J. C. (2002). Robust monetary policy rules with unknown natural rates. Brookings Papers on Economic Activity, 2:63-118.

Persson, T. and Tabellini, G. (2000). Political Economics: Explaining Economic Policy. MIT Press, Cambridge, Massachusetts.

Primiceri, G. (2006). Why inflation rose and fell: Policy-makers' beliefs and us postwar stabilization policy. Quarterly Journal of Economics, 121(3):867-901.

Reis, R. (2003). Where is the natural rate? rational policy mistakes and persistent deviations of inflation from target. Advance in Macroeconomics, 3(1):1-38.

Rudebusch, G. (2002). Assesing nominal income rules for monetary policy in an uncertain world. Economic Journal, 112:402-432.

Rudebusch, G. and Wu, T. (2008). A macro-finance model of the term structure, monetary policy and the economy. Economic Journal (forthcoming).

Ruge-Murcia, F. (2003). Does the barro-gordon model explain the behavior of us inflation? a reexamination of the empirical evidence. Journal of Monetary Economics, 50:1375-1390. 
Sarno, L., Thornton, D., and Valente, G. (2007). The empirical failure of the expectations hypothesis of the term structure of bond yields. Journal of Financial and Quantitative Analysis, 42(1):81-100.

Shiller, R. (1979). The volatility of long-term interest rates and expectations models of the term structure. Journal of Political Economy, 87(6):1190-1219.

Sims, C. A. (2002). Solving linear rational expectations models. Computational Economics, 20(1-2):1-20.

Sims, C. A. and Zha, T. (2006). Were there regime switches in us monetary policy? American Economic Review, 96(1):54-81.

Söderlind, P. (1999). Solution and estimation of re macromodels with optimal policy. European Economic Review, 43:813-823.

Staiger, D., Stock, J. H., and Watson, M. W. (1997). The nairu, unemployment and monetary policy. Journal of Economic Perspectives, 11(1):33-49.

Svensson, L. E. and Woodford, M. (2003). Indicator variables for optimal policy. Journal of Monetary Economics, 50:691-720.

Svensson, L. E. and Woodford, M. (2004). Indicator variables for optimal policy under asymmetric information. Journal of Economic Dynamics and Control, 28:661-690.

Svensson, L. E. O. (1997). Optimal inflation targets, "conservative" central banks, and linear inflation contracts. American Economic Review, 87(1):98-114.

Woodford, M. (1999). Commentary: How should monetary policy be conducted in an era of price stability? in New Challenges for Monetary Policy: A Symposium Sponsored by the Federal Reserve Bank of Kansas City, pages 277-316.

Woodford, M. (2003). Interest and Prices. Princeton University Press, Princeton. 


\section{Tables and Figures}

Table 1: U.S. Data

\begin{tabular}{lccc}
\hline \hline & $1960-2005$ & $1960-1978$ & $1983-2005$ \\
\hline \hline \multicolumn{1}{c}{ Standard deviation } & & & \\
Inflation & 2.43 & 2.66 & 0.97 \\
Unemployment & 1.45 & 1.36 & 1.27 \\
Short-term interest rate & 3.32 & 2.33 & 2.54 \\
5-year bonds & 2.65 & 1.57 & 2.38 \\
10-year bonds & 2.55 & 1.56 & 2.26 \\
$\quad$ Correlation with short-term rate & & & \\
Inflation & 0.67 & 0.82 & 0.45 \\
5-year bonds & 0.91 & 0.82 & 0.92 \\
10-year bonds & 0.87 & 0.76 & 0.87 \\
\hline \hline
\end{tabular}

Annualized data

Table 2: Distribution of the Parameters for the U.S. between 1960-1978

\begin{tabular}{lccc|cccccc}
\hline \hline & & Prior & \multicolumn{5}{c}{ Posterior 1960-1978 } \\
& Density & Mode & St. Error & \multicolumn{5}{c}{ Discretion } & \multicolumn{4}{c}{ Commitment } \\
& & & $5 \%$ & Mean & $95 \%$ & $5 \%$ & Mean & $95 \%$ \\
\hline \hline$\sigma_{\varepsilon}$ & Gamma & 0.10 & 0.05 & 0.28 & 0.33 & 0.37 & 0.26 & 0.31 & 0.35 \\
$\sigma_{\chi}$ & Gamma & 0.10 & 0.05 & 0.27 & 0.31 & 0.35 & 0.27 & 0.31 & 0.36 \\
$\sigma_{\eta}$ & Gamma & 0.10 & 0.05 & 0.15 & 0.17 & 0.20 & 0.16 & 0.18 & 0.21 \\
$\sigma_{\xi}$ & Gamma & 0.10 & 0.05 & 0.07 & 0.09 & 0.12 & 0.21 & 0.25 & 0.30 \\
$\rho$ & Beta & 0.95 & 0.005 & 0.959 & 0.964 & 0.970 & 0.974 & 0.977 & 0.981 \\
$\gamma$ & Beta & 0.95 & 0.02 & 0.974 & 0.982 & 0.989 & 0.967 & 0.976 & 0.984 \\
$\lambda$ & Normal & 1.00 & 0.20 & 0.72 & 1.02 & 1.33 & 1.34 & 1.61 & 1.88 \\
$\theta$ & Gamma & 0.10 & 0.02 & 0.065 & 0.091 & 0.121 & 0.018 & 0.023 & 0.029 \\
$\sigma_{5}$ & Gamma & 0.10 & 0.05 & 0.02 & 0.04 & 0.06 & 0.04 & 0.06 & 0.09 \\
$\sigma_{10}$ & Gamma & 0.10 & 0.05 & 0.09 & 0.10 & 0.12 & 0.11 & 0.14 & 0.16 \\
\hline \hline
\end{tabular}


Table 3: Distribution of the Parameters for the U.S. between 1983-2005

\begin{tabular}{lccc|cccccc}
\hline \hline & & \multicolumn{3}{c|}{ Prior } & \multicolumn{5}{c}{ Posterior 1983-2005 } \\
& Density & Mode & St. Error & \multicolumn{4}{c}{ Discretion } & \multicolumn{4}{c}{ Commitment } \\
& & & $5 \%$ & Mean & $95 \%$ & $5 \%$ & Mean & $95 \%$ \\
\hline \hline$\sigma_{\varepsilon}$ & Gamma & 0.10 & 0.05 & 0.44 & 0.49 & 0.55 & 0.46 & 0.51 & 0.58 \\
$\sigma_{\chi}$ & Gamma & 0.10 & 0.05 & 0.17 & 0.19 & 0.21 & 0.13 & 0.15 & 0.17 \\
$\sigma_{\eta}$ & Gamma & 0.10 & 0.05 & 0.12 & 0.13 & 0.15 & 0.01 & 0.02 & 0.03 \\
$\sigma_{\xi}$ & Gamma & 0.10 & 0.05 & 0.06 & 0.08 & 0.10 & 0.17 & 0.20 & 0.23 \\
$\rho$ & Beta & 0.95 & 0.005 & 0.973 & 0.976 & 0.980 & 0.975 & 0.979 & 0.982 \\
$\gamma$ & Beta & 0.95 & 0.02 & 0.968 & 0.977 & 0.986 & 0.949 & 0.959 & 0.969 \\
$\lambda$ & Normal & 1.00 & 0.20 & 0.88 & 1.14 & 1.41 & 1.48 & 1.73 & 1.99 \\
$\theta$ & Gamma & 0.10 & 0.02 & 0.062 & 0.083 & 0.107 & 0.027 & 0.032 & 0.039 \\
$\sigma_{5}$ & Gamma & 0.10 & 0.05 & 0.01 & 0.03 & 0.04 & 0.23 & 0.27 & 0.30 \\
$\sigma_{10}$ & Gamma & 0.10 & 0.05 & 0.08 & 0.09 & 0.101 & 0.30 & 0.35 & 0.39 \\
\hline \hline
\end{tabular}

Table 4: U.S. Variance Decomposition Under Discretion

\begin{tabular}{lcccc|cccc}
\hline \hline & \multicolumn{9}{c|}{$1960-1978$} & \multicolumn{5}{c}{$1983-2005$} \\
\multicolumn{1}{c}{ Shock } & $\pi$ & $i$ & $i^{5}$ & $i^{10}$ & $\pi$ & $i$ & $i^{5}$ & $i^{10}$ \\
\hline \hline 1-year horizon & & & & & & & \\
$\eta$ & 0 & 60 & 0 & 0 & 0 & 40 & 0 & 0 \\
$\varepsilon$ & 54 & 2 & 0 & 0 & 69 & 3 & 0 & 0 \\
$\chi$ & 0 & 0 & 1 & 1 & 0 & 0 & 0 & 0 \\
$\xi$ & 46 & 38 & 96 & 67 & 31 & 57 & 99 & 84 \\
$\tau^{5}$ & - & - & 4 & - & - & - & 1 & - \\
$\tau^{10}$ & - & - & - & 33 & - & - & - & 16 \\
$10-$ year horizon & & & & & & & & \\
$\eta$ & 0 & 29 & 0 & 0 & 0 & 12 & 0 & 0 \\
$\varepsilon$ & 24 & 1 & 0 & 0 & 31 & 1 & 0 & 0 \\
$\chi$ & 0 & 1 & 1 & 1 & 0 & 0 & 0 & 0 \\
$\xi$ & 76 & 69 & 98 & 87 & 69 & 87 & 1 & 96 \\
$\tau^{5}$ & - & - & 1 & - & - & - & 0 & - \\
$\tau^{10}$ & - & - & - & 11 & - & - & - & 04 \\
\hline \hline
\end{tabular}

Calculated using the posterior mean of the parameters. 
Table 5: U.S. Variance Decomposition Under Commitment

\begin{tabular}{lcccc|cccc}
\hline \hline & \multicolumn{4}{c|}{$1960-1978$} & \multicolumn{4}{c}{$1983-2005$} \\
\multicolumn{1}{c}{ Shock } & $\pi$ & $i$ & $i^{5}$ & $i^{10}$ & $\pi$ & $i$ & $i^{5}$ & $i^{10}$ \\
\hline \hline 1-year horizon & & & & & & & & \\
$\eta$ & 0 & 76 & 0 & 0 & 0 & 2 & 0 & 0 \\
$\varepsilon$ & 61 & 0 & 0 & 0 & 82 & 1 & 0 & 0 \\
$\chi$ & 0 & 0 & 2 & 1 & 0 & 1 & 0 & 0 \\
$\xi$ & 39 & 24 & 82 & 30 & 18 & 96 & 19 & 5 \\
$\tau^{5}$ & - & - & 16 & - & - & - & 80 & - \\
$\tau^{10}$ & - & - & - & 68 & - & - & - & 94 \\
10 -year horizon & & & & & & & & \\
$\eta$ & 0 & 49 & 0 & 0 & 0 & 1 & 0 & 0 \\
$\varepsilon$ & 32 & 0 & 1 & 1 & 59 & 2 & 1 & 1 \\
$\chi$ & 0 & 2 & 4 & 4 & 0 & 1 & 1 & 0 \\
$\xi$ & 68 & 49 & 89 & 51 & 41 & 96 & 38 & 11 \\
$\tau^{5}$ & - & - & 6 & - & - & - & 60 & - \\
$\tau^{10}$ & - & - & - & 45 & - & - & - & 88 \\
\hline \hline Cal
\end{tabular}

Calculated using the posterior mean of the parameters.

Table 6: Simulated Bond Returns Volatility for the U.S.

\begin{tabular}{lccc|ccc}
\hline \hline & \multicolumn{3}{c|}{$1960-1978$} & \multicolumn{3}{c}{$1983-2005$} \\
& Data & Discretion & Commitment & Data & Discretion & Commitment \\
\hline \hline 5-year returns & 0.39 & 0.44 & 0.32 & 0.54 & 0.54 & 0.29 \\
10-year returns & 0.28 & 0.32 & 0.21 & 0.47 & 0.43 & 0.19 \\
\hline \hline
\end{tabular}

Bond returns volatility is calculated as $\operatorname{Std}\left(i_{t}^{m}-i_{t-1}^{m}\right)$, performing 1,000

simulations for 75 periods using the posterior mean of the parameters. Annualized data.

Table 7: Model Comparison for the U.S.

\begin{tabular}{ccc|c}
\hline \hline & \multicolumn{2}{c|}{ Log marginal likelihood } & Posterior \\
& Discretion & Commitment & Odds Ratio \\
\hline \hline $1960-1978$ & -33.95 & -107.28 & $10^{32}$ \\
$1983-2005$ & -13.29 & -159.66 & $10^{63}$ \\
\hline \hline
\end{tabular}

The marginal likelihood is approximated by the modified harmonic mean.

Posterior odds of the hypothesis discretion versus commitment. 
Table 8: U.K. and U.S. Data before and after 1998

\begin{tabular}{lcccc}
\hline \hline & \multicolumn{2}{c}{ U.K. } & \multicolumn{2}{c}{ U.S. } \\
& $1983-1997$ & $1998-2005$ & $1983-1997$ & $1998-2005$ \\
\hline \hline \multicolumn{1}{c}{ Standard deviation } & & & & \\
Inflation & 2.96 & 1.32 & 0.98 & 0.83 \\
Unemployment & 1.94 & 0.53 & 1.21 & 0.73 \\
Short-term interest rate & 2.93 & 1.17 & 2.13 & 1.94 \\
10-year bonds & 1.51 & 0.44 & 1.92 & 0.76 \\
$\quad$ Correlation with short-term rate & & & & \\
Inflation & 0.51 & -0.15 & 0.58 & -0.21 \\
10-year bonds & 0.83 & 0.71 & 0.85 & 0.82 \\
\hline \hline
\end{tabular}

Annualized data

Table 9: Distribution of the Parameters for the U.K.

\begin{tabular}{lccc|cccc}
\hline \hline \multirow{2}{*}{ Parameter } & \multicolumn{3}{c|}{ Prior } & \multicolumn{4}{c}{ Posterior Mean } \\
& Density & Mode & St. Error & 1983-1997 & $1998-2005$ \\
& & & & Dis. & Com. & Dis. & Com. \\
\hline \hline$\sigma_{\varepsilon}$ & Gamma & 0.10 & 0.05 & 0.549 & 0.569 & 0.314 & 0.359 \\
$\sigma_{\chi}$ & Gamma & 0.10 & 0.05 & 0.325 & 0.301 & 0.119 & 0.123 \\
$\sigma_{\eta}$ & Gamma & 0.10 & 0.05 & 0.121 & 0.070 & 0.085 & 0.033 \\
$\sigma_{\xi}$ & Gamma & 0.10 & 0.05 & 0.171 & 0.311 & 0.064 & 0.103 \\
$\rho$ & Beta & 0.95 & 0.005 & 0.954 & 0.968 & 0.950 & 0.953 \\
$\gamma$ & Beta & 0.95 & 0.02 & 0.967 & 0.946 & 0.940 & 0.915 \\
$\lambda$ & Normal & 1.00 & 0.20 & 1.269 & 1.519 & 1.182 & 1.190 \\
$\theta$ & Gamma & 0.10 & 0.02 & 0.077 & 0.043 & 0.085 & 0.096 \\
$\sigma_{10}$ & Gamma & 0.10 & 0.05 & 0.129 & 0.236 & 0.059 & 0.080 \\
\hline \hline
\end{tabular}

Table 10: Model Comparison for the U.K.

\begin{tabular}{ccc|c}
\hline \hline & \multicolumn{2}{c|}{ Log marginal likelihood } & Posterior \\
& Discretion & Commitment & Odds Ratio \\
\hline \hline $1983-1997$ & -129.50 & -169.75 & $10^{17}$ \\
$1998-2005$ & -9.56 & -7.93 & 0.20 \\
\hline \hline
\end{tabular}

The marginal likelihood is approximated by the modified harmonic mean.

Posterior odds of the hypothesis discretion versus commitment. 
Table 11: Symmetric Imperfect Information and Optimal Filters

\begin{tabular}{lccc}
\hline \hline & U.S. Data & \multicolumn{2}{c}{ Simulated data } \\
& 1960-1978 & Discretion & Commitment \\
\hline \hline \multicolumn{1}{c}{ Standard Deviation } & & & \\
Inflation & 2.66 & 2.22 & 3.65 \\
Unemployment $_{\text {Short-term interest rate }}$ & 1.36 & 0.42 & 0.98 \\
10-year interest rate $^{1}$ & 2.33 & 2.38 & 2.95 \\
$\quad 1.56$ & 0.98 & 0.54 \\
$\quad$ Correlation with Short-Term Rate ${ }^{1}$ & & & \\
Inflation & 0.82 & 0.99 & 0.99 \\
10-year interest rate & 0.76 & 0.69 & 0.65 \\
$\quad$ & - & & \\
simulated $\rho$ & - & 0.95 & 0.95 \\
\hline \hline
\end{tabular}

Performing 1,000 simulations for 75 periods.

${ }^{1}$ Calculated for the case of constant term premiums. 

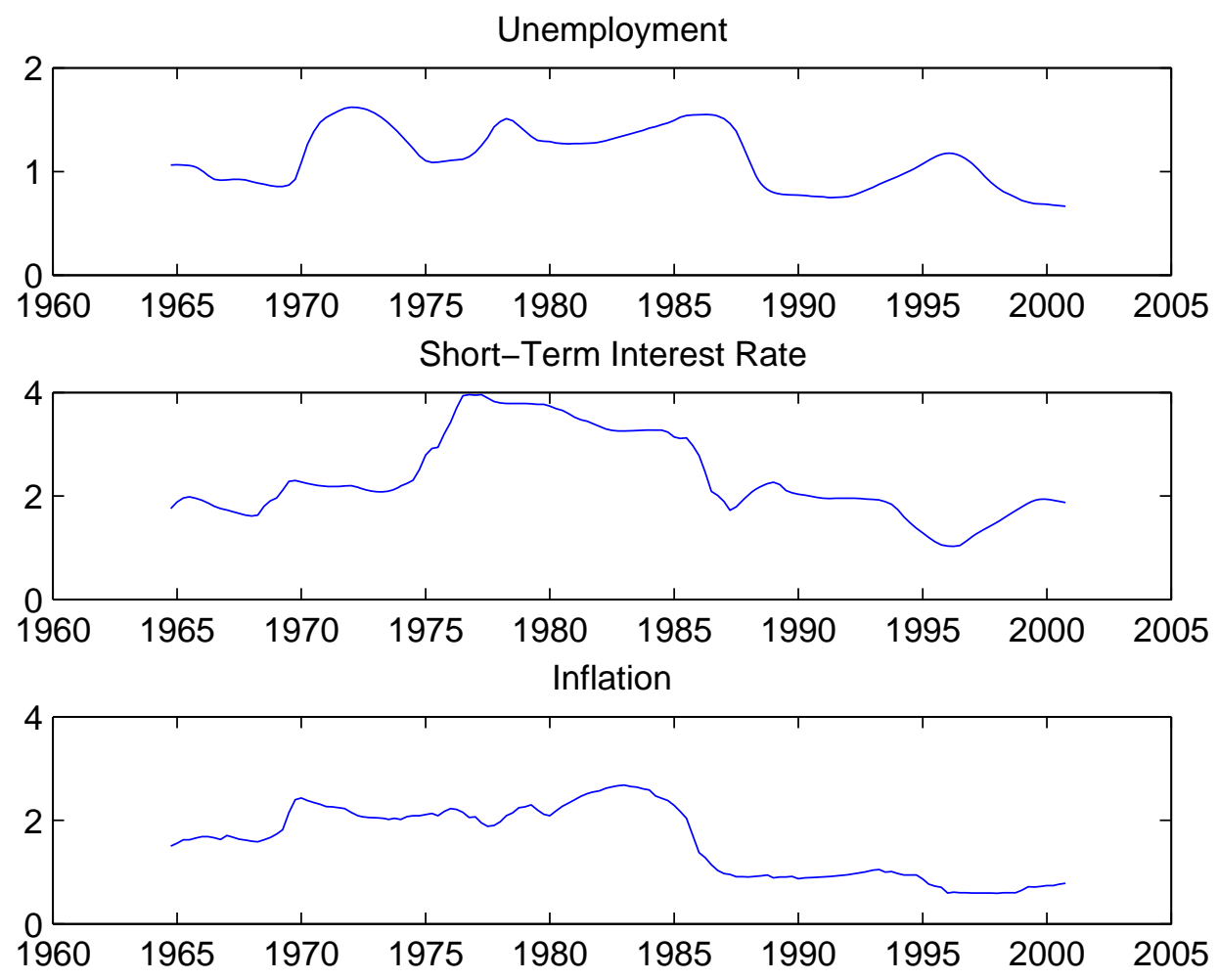

Figure 1: 10 years rolling standard deviation (centered) 

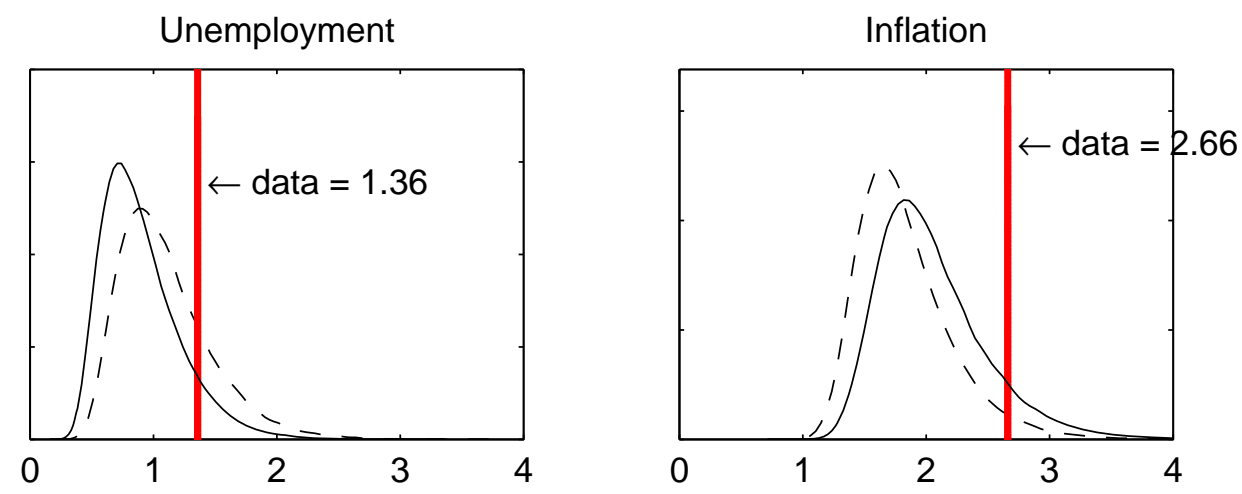

\section{Short Term Interest Rate}

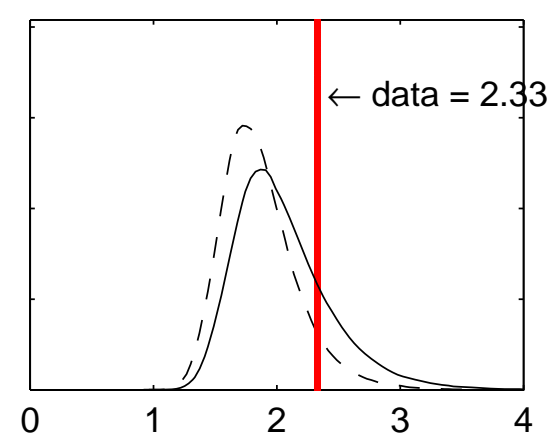

Figure 2: Posterior predictive distribution of the standard deviation for U.S. data between 1960-1978. Solid line distribution: optimal monetary policy under discretion. Dashed line distribution: optimal monetary policy under commitment. Bar: actual data. 

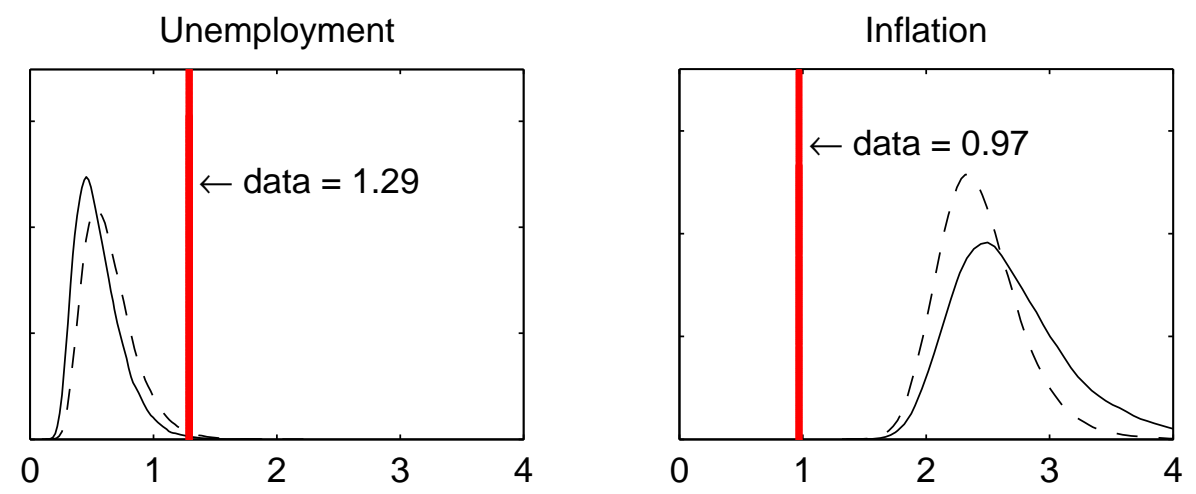

\section{Short Term Interest Rate}

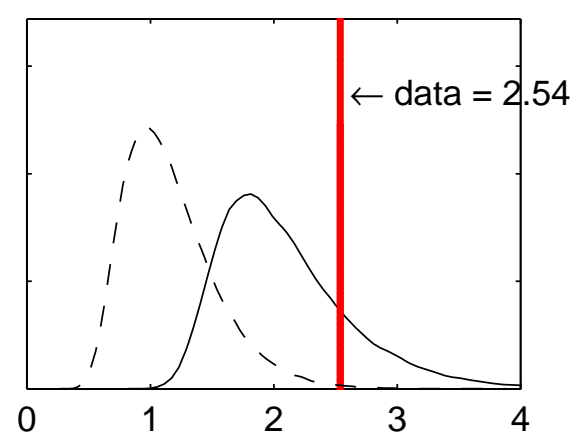

Figure 3: Posterior predictive distribution of the standard deviation for U.S. data between 1983-2005. Solid line distribution: optimal monetary policy under discretion. Dashed line distribution: optimal monetary policy under commitment. Bar: actual data. 
Excluding term premium shocks $1960-1978$
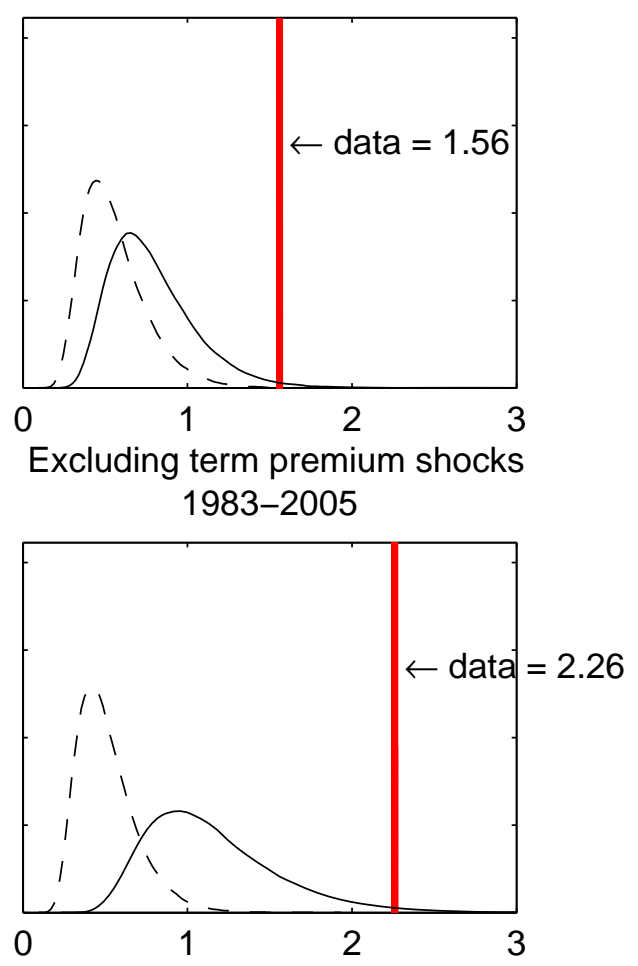

Including term premium shocks $1960-1978$

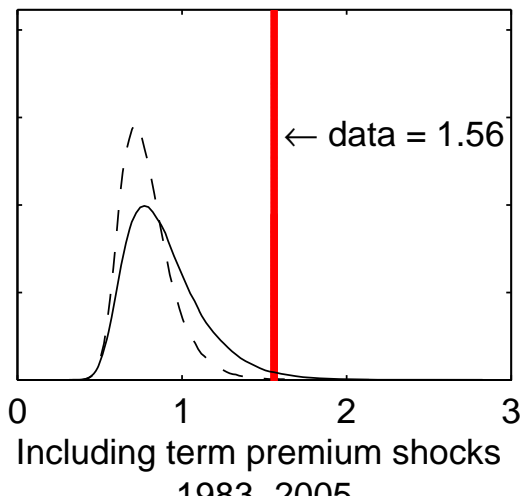
1983-2005

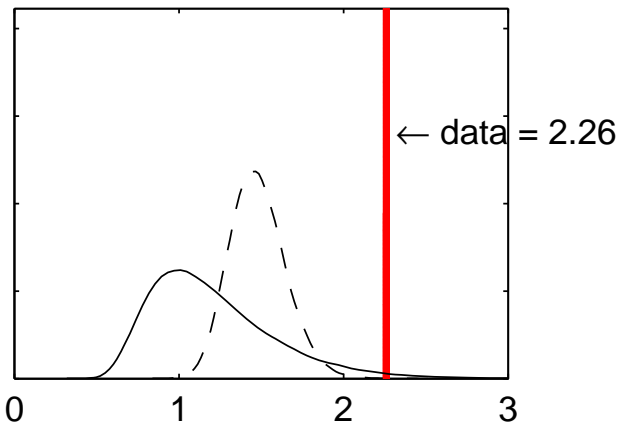

Figure 4: Posterior predictive distribution of the standard deviation for U.S. 10-year interest rates. Solid line distribution: optimal monetary policy under discretion. Dashed line distribution: optimal monetary policy under commitment. Bar: actual data. 

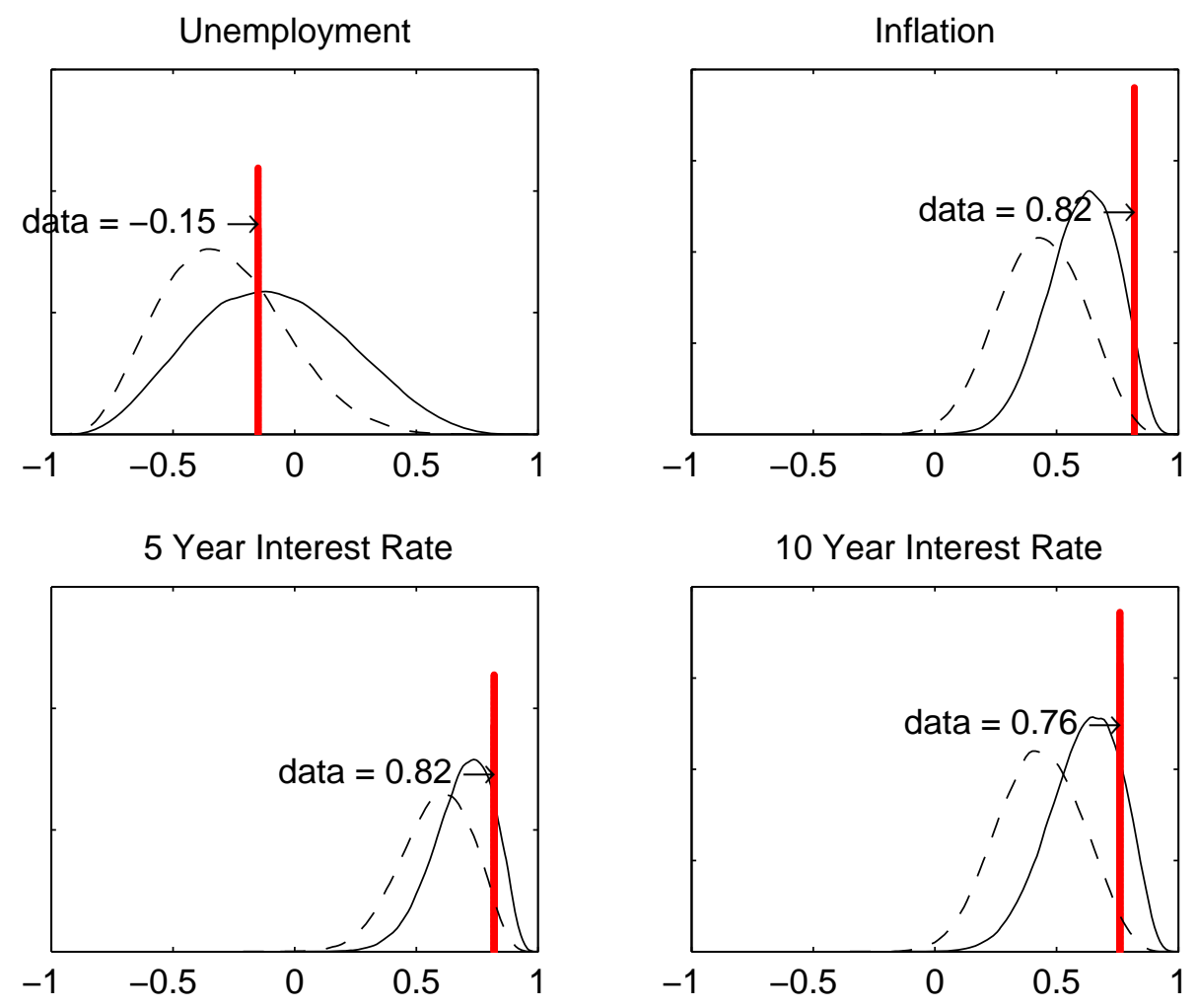

Figure 5: Posterior predictive correlation with the short-term interest rate for U.S. data between 1960-1978 (including term premium shocks). Solid line distribution: optimal monetary policy under discretion. Dashed line distribution: optimal monetary policy under commitment. Bar: actual data 

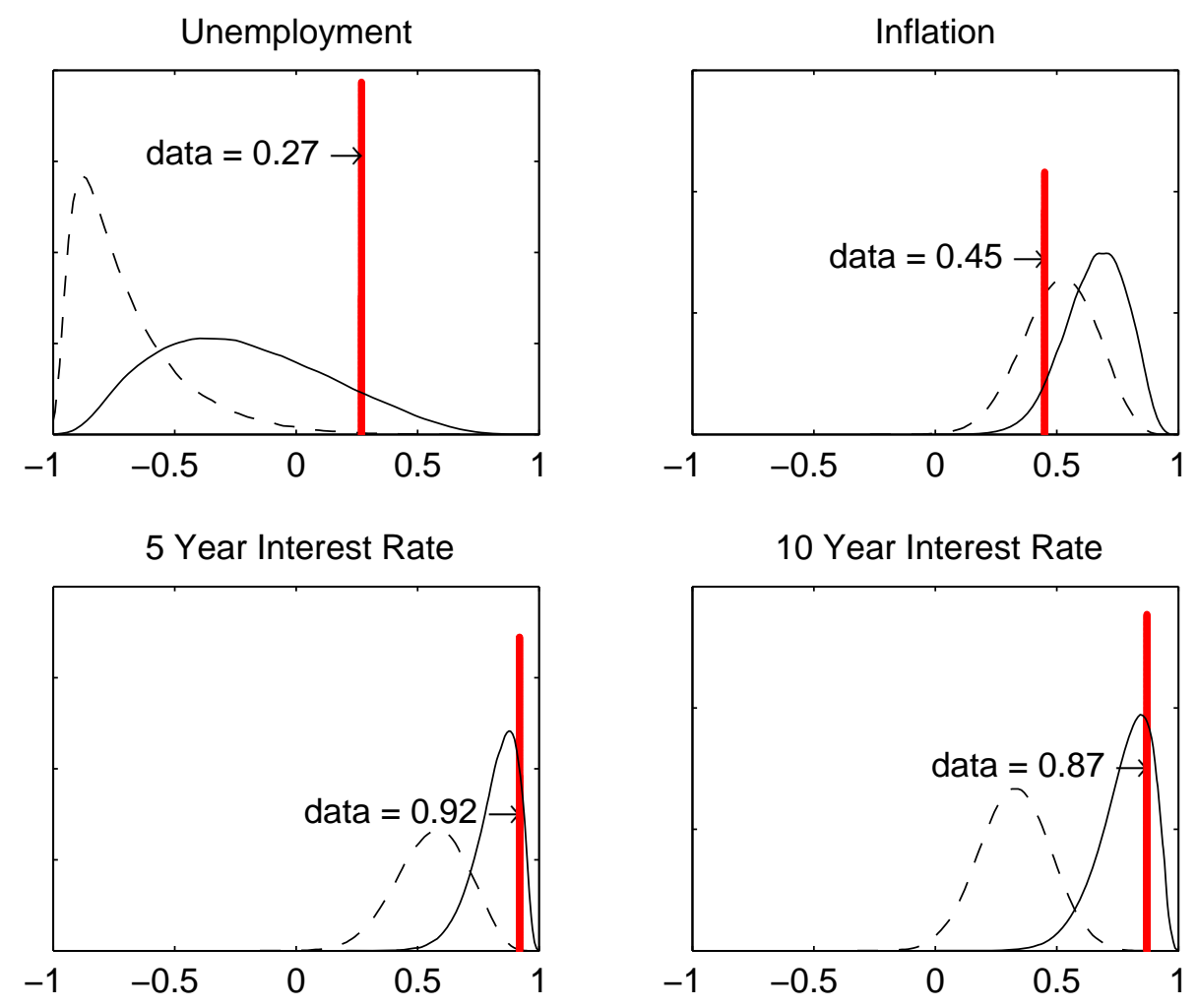

Figure 6: Posterior predictive correlation with the short-term interest rate for U.S. data between 1983-2005 (including term premium shocks). Solid line distribution: optimal monetary policy under discretion. Dashed line distribution: optimal monetary policy under commitment. Bar: actual data 
10 Year Interest Rate

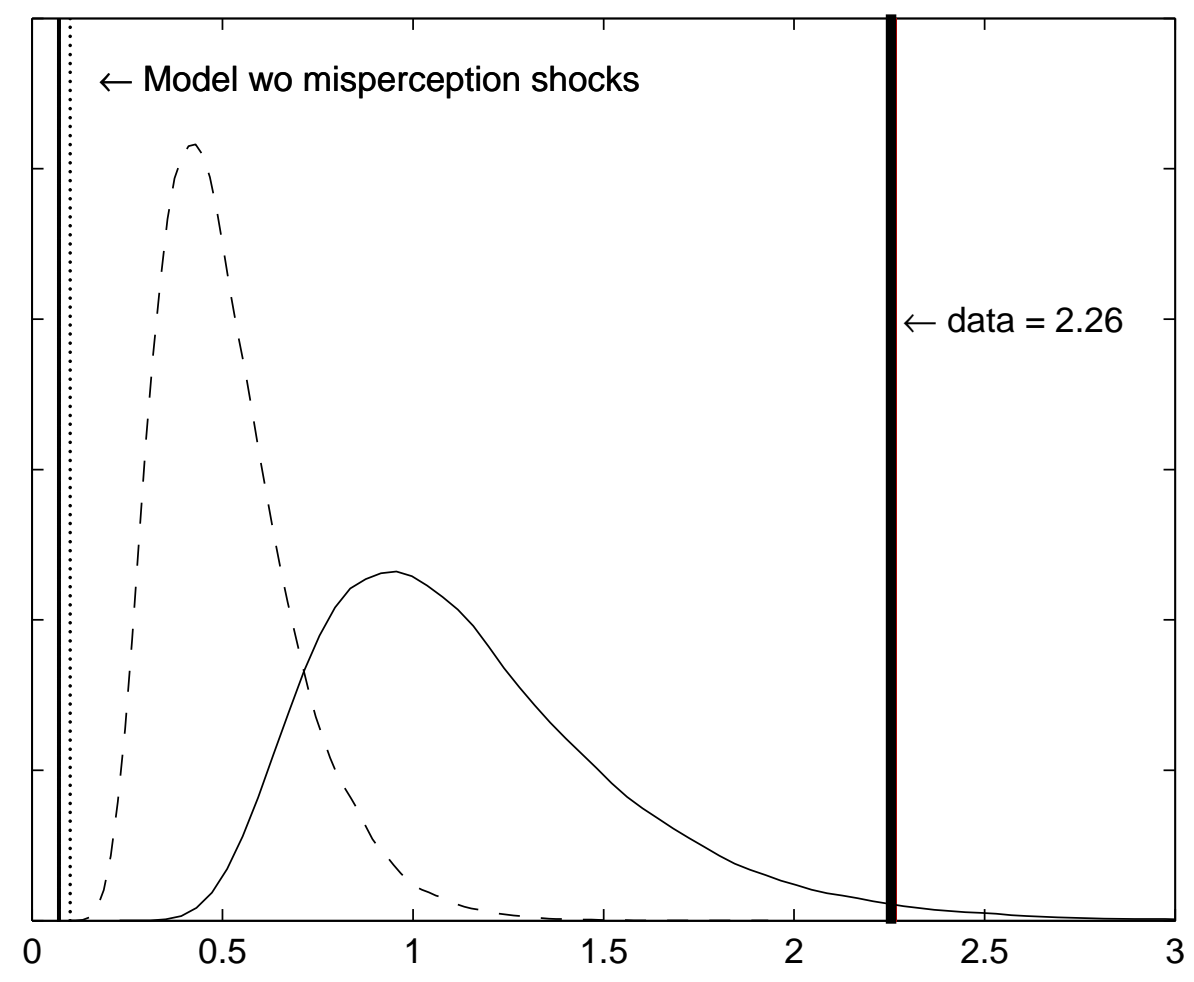

Figure 7: Simulated standard deviation for U.S. 10 year interest rates between 19832005. Bar: actual data. Solid line distribution: optimal monetary policy under discretion (exc. term premium shocks). Dashed line distribution: optimal monetary policy under commitment (exc. term premium shocks). Solid line: optimal monetary policy under discretion shutting off misperception shocks. Dashed line: optimal monetary policy under commitment shutting off misperception shocks. 


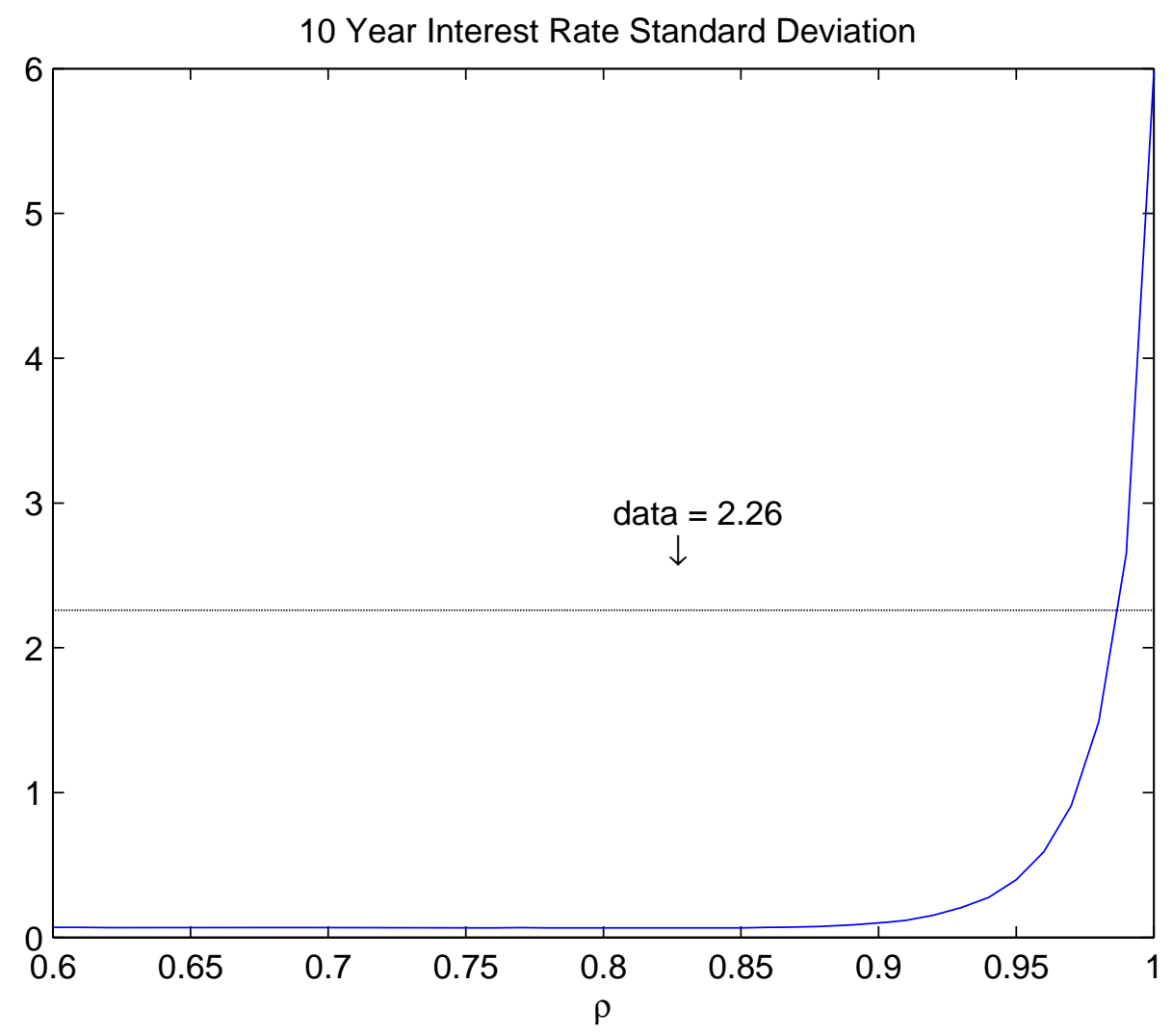

Figure 8: Simulated standard deviation of 10 year interest rates using the U.S. estimated mean between 1983 and 2005 under discretionary monetary policy and varying the values of $\rho$. 

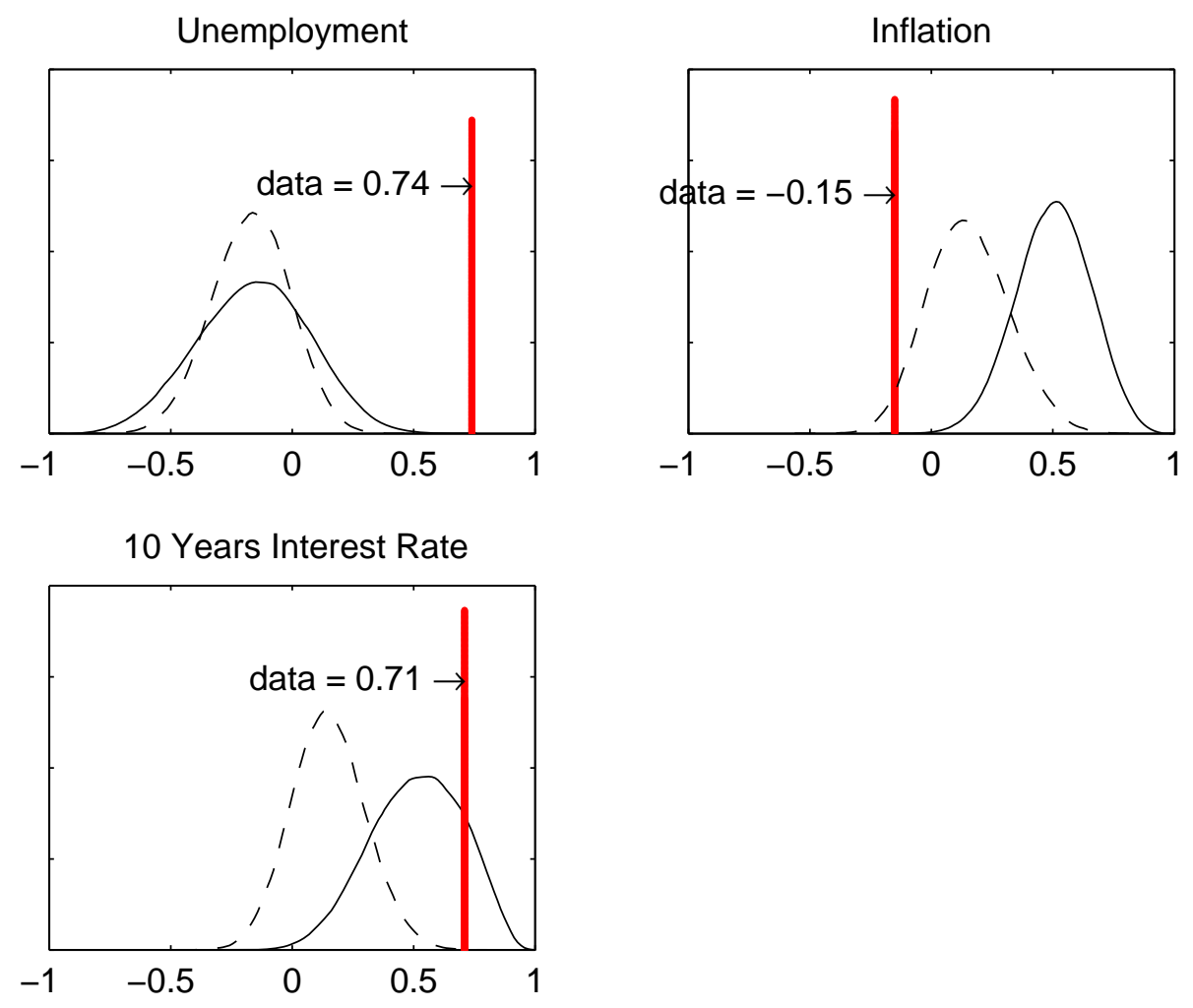

Figure 9: Posterior predictive correlation with the short-term interest rate for U.K. data between 1998-2005 (including term premium shocks). Solid line distribution: optimal monetary policy under discretion. Dashed line distribution: optimal monetary policy under commitment. Bar: actual data 


\section{Excluding term premium shocks} 1983-1997

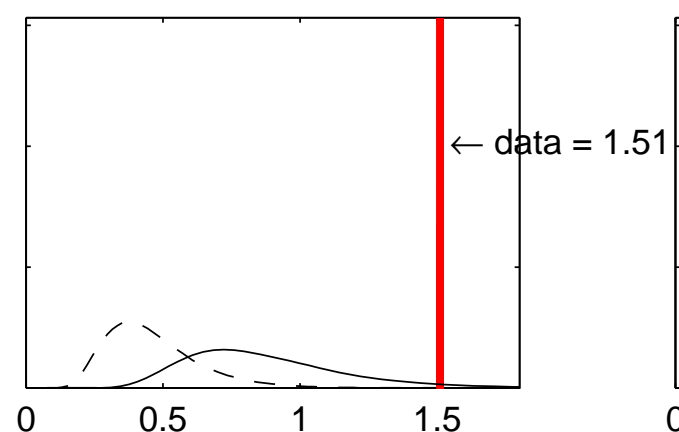

Excluding term premium shocks 1998-2005

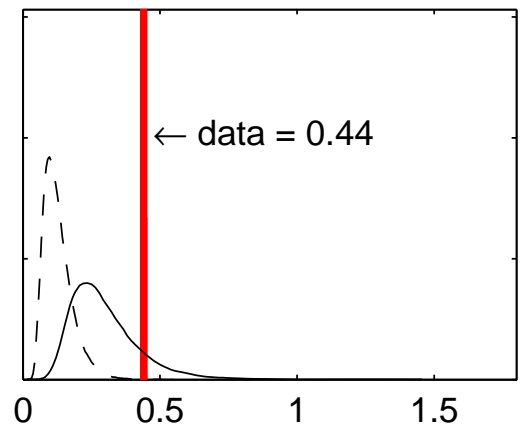

Including term premium shocks

1983-1997

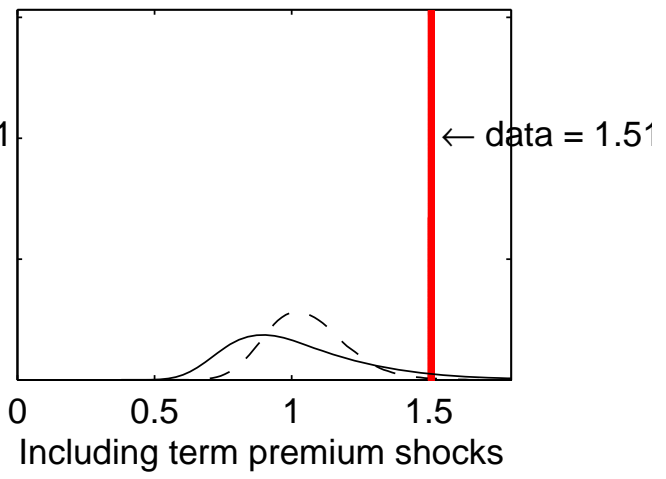

1998-2005

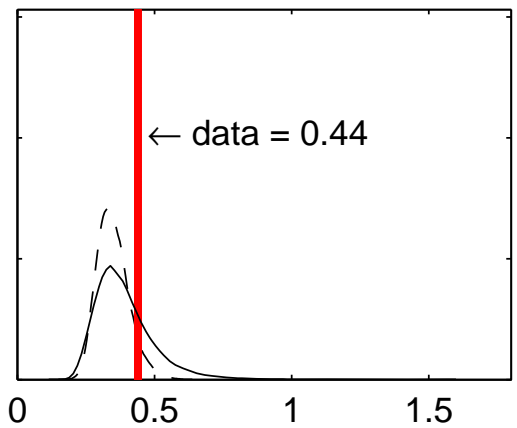

Figure 10: Posterior predictive distribution of the standard deviation for U.K. 10 year interest rates. Solid line distribution: optimal monetary policy under discretion. Dashed line distribution: optimal monetary policy under commitment. Bar: actual data. 


\section{Earlier Working Papers:}

For a complete list of Working Papers published by Sveriges Riksbank, see www.riksbank.se

Estimation of an Adaptive Stock Market Model with Heterogeneous Agents by Henrik Amilon ........ 2005:177

Some Further Evidence on Interest-Rate Smoothing: The Role of Measurement

Errors in the Output Gap by Mikael Apel and Per Jansson.....

Bayesian Estimation of an Open Economy DSGE Model with Incomplete Pass-Through

by Malin Adolfson, Stefan Laséen, Jesper Lindé and Mattias Villani

Are Constant Interest Rate Forecasts Modest Interventions? Evidence from

an Estimated Open Economy DSGE Model of the Euro Area by Malin Adolfson,

Stefan Laséen, Jesper Lindé and Mattias Villani

Inference in Vector Autoregressive Models with an Informative

Prior on the Steady State by Mattias Villani

Bank Mergers, Competition and Liquidity by Elena Carletti, Philipp Hartmann

and Giancarlo Spagnolo

Testing Near-Rationality using Detailed Survey Data

by Michael F. Bryan and Stefan Palmqvist.

Exploring Interactions between Real Activity and the Financial Stance

by Tor Jacobson, Jesper Lindé and Kasper Roszbach

Two-Sided Network Effects, Bank Interchange Fees,

and the Allocation of Fixed Costs by Mats A. Bergman .....

Trade Deficits in the Baltic States: How Long Will the Party Last?

by Rudolfs Bems and Kristian Jönsson.

Real Exchange Rate and Consumption Fluctuations follwing Trade Liberalization

by Kristian Jönsson

Modern Forecasting Models in Action: Improving Macroeconomic Analyses at Central Banks

by Malin Adolfson, Michael K. Andersson, Jesper Lindé, Mattias Villani and Anders Vredin.....

Bayesian Inference of General Linear Restrictions on the Cointegration Space by Mattias Villani.

2005:189

Forecasting Performance of an Open Economy Dynamic Stochastic General Equilibrium Model

by Malin Adolfson, Stefan Laséen, Jesper Lindé and Mattias Villani

Forecast Combination and Model Averaging using Predictive Measures

by Jana Eklund and Sune Karlsson.

Swedish Intervention and the Krona Float, 1993-2002

by Owen F. Humpage and Javiera Ragnartz

A Simultaneous Model of the Swedish Krona, the US Dollar and the Euro

by Hans Lindblad and Peter Sellin

Testing Theories of Job Creation: Does Supply Create Its Own Demand?

by Mikael Carlsson, Stefan Eriksson and Nils Gottfries.....

Down or Out: Assessing The Welfare Costs of Household Investment Mistakes

by Laurent E. Calvet, John Y. Campbell and Paolo Sodini

Efficient Bayesian Inference for Multiple Change-Point and Mixture Innovation Models

by Paolo Giordani and Robert Kohn

Derivation and Estimation of a New Keynesian Phillips Curve in a Small Open Economy

by Karolina Holmberg

Technology Shocks and the Labour-Input Response: Evidence from Firm-Level Data

by Mikael Carlsson and Jon Smedsaas

Monetary Policy and Staggered Wage Bargaining when Prices are Sticky

by Mikael Carlsson and Andreas Westermark

The Swedish External Position and the Krona by Philip R. Lane

Price Setting Transactions and the Role of Denominating Currency in FX Markets

by Richard Friberg and Fredrik Wilander.....

The geography of asset holdings: Evidence from Sweden

by Nicolas Coeurdacier and Philippe Martin

Evaluating An Estimated New Keynesian Small Open Economy Model

by Malin Adolfson, Stefan Laséen, Jesper Lindé and Mattias Villani .......

The Use of Cash and the Size of the Shadow Economy in Sweden

by Gabriela Guibourg and Björn Segendorf

Bank supervision Russian style: Evidence of conflicts between micro- and macro-

prudential concerns by Sophie Claeys and Koen Schoors 
Optimal Monetary Policy under Downward Nominal Wage Rigidity by Mikael Carlsson and Andreas Westermark.

Financial Structure, Managerial Compensation and Monitoring

by Vittoria Cerasi and Sonja Daltung .....

Financial Frictions, Investment and Tobin's q by Guido Lorenzoni and Karl Walentin

Sticky Information vs. Sticky Prices: A Horse Race in a DSGE Framework

by Mathias Trabandt.

Acquisition versus greenfield: The impact of the mode of foreign bank entry

on information and bank lending rates by Sophie Claeys and Christa Hainz

Nonparametric Regression Density Estimation Using Smoothly Varying Normal Mixtures

by Mattias Villani, Robert Kohn and Paolo Giordani

The Costs of Paying - Private and Social Costs of Cash and Card

by Mats Bergman, Gabriella Guibourg and Biörn Segendorf

Using a New Open Economy Macroeconomics model to make real nominal

exchange rate forecasts by Peter Sellin

Introducing Financial Frictions and Unemployment into a Small Open Economy Model

by Lawrence J. Christiano, Mathias Trabandt and Karl Walentin

Earnings Inequality and the Equity Premium by Karl Walentin

Bayesian forecast combination for VAR models by Michael $K$ Andersson and Sune Karlsson 2007:216

Do Central Banks React to House Prices?

by Daria Finocchiaro and Virginia Queijo von Heideken.

The Riksbank's Forecasting Performance

by Michael K. Andersson, Gustav Karlsson and Josef Svensson

Macroeconomic Impact on Expected Default Freqency

by Per Åsberg and Hovick Shahnazarian 
Website: www.riksbank.se 